\title{
Cleanup Verification Package for the 300-8 Waste Site
}

\author{
Prepared for the U.S. Department of Energy
}

by Washington Closure Hanford 


\section{EXECUTIVE SUMMARY}

This cleanup verification package documents completion of remedial action for the 300-8 waste site. The 300-8 site is located within the 300-FF-2 Operable Unit in the 300 Area of the Hanford Site in southeastern Washington State. The site was formerly used to stage scrap metal from the 300 Area in support of a program to recycle aluminum. Staging and loading activities at the site scattered scrap metal over an approximately $34,000-\mathrm{m}^{2}\left(366,000-\mathrm{ft}^{2}\right)$ area, with residual metallic debris generally present within the top $0.4 \mathrm{~m}(1.5 \mathrm{ft})$ of soil.

Site excavation and waste disposal are complete, and post-excavation geophysical surveys confirm the removal of residual metallic debris. The exposed surfaces have been sampled and analyzed to verify attainment of the remedial action goals. Results of the sampling, laboratory analyses, and data evaluations for the 300-8 site indicate that all remedial action objectives and goals for direct exposure, protection of groundwater, and protection of the Columbia River have been met for industrial land use (Table ES-1).

Because residual soil concentrations indicated that cleanup levels for more stringent land uses may have been achieved for the 300-8 site, a supplemental evaluation was performed against unrestricted land-use cleanup objectives established in the Explanation of Significant Differences for the 300-FF-2 Operable Unit Record of Decision (EPA 2004).

Results of the evaluation (Table ES-2) demonstrate that residual contaminant concentrations do not preclude any future uses (as bounded by the rural-residential scenario) and allow for unrestricted use of shallow zone soils (i.e., surface to $4.6 \mathrm{~m}$ [15 ft] deep). This site does not have a deep zone; therefore, no deep zone institutional controls are required. 
The site meets cleanup standards and has been reclassified as "interim closed out" in accordance with the Hanford Federal Facility Agreement and Consent Order (Ecology et al. 1989) and the Waste Site Reclassification Guideline TPA-MP-14 (RL-TPA-90-0001) (DOE-RL 1998). A copy of the waste site reclassification form is included as Attachment ES-1. 


\section{Table ES-1. Summary of Cleanup Verification Results for the 300-8 Waste Site - Industrial Land Use.}

\begin{tabular}{|c|c|c|c|}
\hline $\begin{array}{l}\text { Regulatory } \\
\text { Requirement }\end{array}$ & Remedial Action Goals & Results & $\begin{array}{l}\text { Remedial } \\
\text { Action } \\
\text { Objectives } \\
\text { Attained? }\end{array}$ \\
\hline $\begin{array}{l}\text { Direct Exposure - } \\
\text { Radionuclides }\end{array}$ & $\begin{array}{l}\text { Attain } 15 \text { mrem/yr dose rate above } \\
\text { background over } 1,000 \text { years. Attain } \\
\text { the CERCLA risk range of } 10^{-4} \text { to } \\
10^{-6} \text {. }\end{array}$ & $\begin{array}{l}\text { No radionuclide COCs were detected } \\
\text { above background levels. }\end{array}$ & Yes \\
\hline $\begin{array}{l}\text { Direct Exposure - } \\
\text { Nonradionuclides }\end{array}$ & Attain individual COC RAGs. & $\begin{array}{l}\text { All individual COC concentrations are } \\
\text { below the RAGs. }\end{array}$ & Yes \\
\hline \multirow{4}{*}{$\begin{array}{l}\text { Meet } \\
\text { Nonradionuclide Risk } \\
\text { Requirements }\end{array}$} & $\begin{array}{l}\text { Hazard quotient of }<1 \text { for } \\
\text { noncarcinogens. }\end{array}$ & \multirow{2}{*}{$\begin{array}{l}\text { Hazard quotients were not calculated } \\
\text { because concentrations of the only } \\
\text { nonradionuclide COC (beryllium) were } \\
\text { below statistical background levels. }\end{array}$} & \multirow{4}{*}{ Yes } \\
\hline & $\begin{array}{l}\text { Cumulative hazard quotient of }<1 \text { for } \\
\text { noncarcinogens. }\end{array}$ & & \\
\hline & $\begin{array}{l}\text { Excess cancer risk of }<1 \times 10^{-5} \text { for } \\
\text { individual carcinogens. }\end{array}$ & \multirow{2}{*}{$\begin{array}{l}\text { Excess cancer risks were not } \\
\text { calculated because concentrations of } \\
\text { the only nonradionuclide COC } \\
\text { (beryllium) were below statistical } \\
\text { background levels. }\end{array}$} & \\
\hline & $\begin{array}{l}\text { Attain a total excess cancer risk of } \\
<1 \times 10^{-5} \text { for carcinogens. }\end{array}$ & & \\
\hline \multirow{4}{*}{$\begin{array}{l}\text { Groundwater/River } \\
\text { Protection - } \\
\text { Radionuclides }\end{array}$} & $\begin{array}{l}\text { Attain single-COC groundwater and } \\
\text { river protection RAGs. }\end{array}$ & $\begin{array}{l}\text { All single-COC groundwater and river } \\
\text { RAGs have been attained. }\end{array}$ & \multirow{4}{*}{ Yes } \\
\hline & $\begin{array}{l}\text { Attain National Primary Drinking } \\
\text { Water Standards: } 4 \text { mrem/yr } \\
\text { (beta/gamma) dose rate to target } \\
\text { receptor/organs. }\end{array}$ & $\begin{array}{l}\text { No beta/gamma-emitting COCs were } \\
\text { identified for this site. }\end{array}$ & \\
\hline & $\begin{array}{l}\text { Meet drinking water standards for } \\
\text { nonuranium alpha emitters: the } \\
\text { more stringent of the } 15 \mathrm{pCi} / \mathrm{L} \mathrm{MCL} \\
\text { or } 1 / 25^{\text {th }} \text { of the derived concentration } \\
\text { guide per DOE Order } 5400.5^{b}\end{array}$ & $\begin{array}{l}\text { No beta/gamma-emitting COCs were } \\
\text { identified for this site. }\end{array}$ & \\
\hline & $\begin{array}{l}\text { Meet total uranium standard of } \\
21.2 \mathrm{pCi} / \mathrm{L} \text {. }\end{array}$ & $\begin{array}{l}\text { Uranium statistical values are below } \\
\text { background levels for this site. }\end{array}$ & \\
\hline $\begin{array}{l}\text { Groundwater/River } \\
\text { Protection - } \\
\text { Nonradionuclides }\end{array}$ & $\begin{array}{l}\text { Attain individual nonradionuclide } \\
\text { groundwater and river cleanup } \\
\text { requirements. }\end{array}$ & $\begin{array}{l}\text { All the groundwater and river RAGs } \\
\text { have been attained. }\end{array}$ & Yes \\
\hline $\begin{array}{l}\text { Supporting } \\
\text { Information }\end{array}$ & \multicolumn{3}{|c|}{ 300-8 Cleanup verification sample location design (Appendix C). } \\
\hline
\end{tabular}

\footnotetext{
a "National Primary Drinking Water Regulations" (40 Code of Federal Regulations 141).

${ }^{b}$ Radiation Protection of the Public and the Environment (DOE Order 5400.5).

${ }^{\circ}$ Based on the isotopic distribution of uranium in the Hanford Site background, the $30 \mathrm{\mu g} / \mathrm{L} \mathrm{MCL} \mathrm{(65} \mathrm{Federal} \mathrm{Register} \mathrm{76708)}$ corresponds to $21.2 \mathrm{pCi} / \mathrm{L}$. Concentration-to-activity calculations are documented in Calculation of Total Uranium Activity Corresponding to a Maximum Contaminant Level for Total Uranium of 30 Micrograms per Liter in Groundwater, 0100X-CA-V0038 (BHI 2001).

"300-8 Sites Shallow Zone Sampling Plan, 0300X-CA-V0057, Rev. 0, Bechtel Hanford, Inc., Richland, Washington.

e 300-8 Waste Site Cleanup Verification 95\% UCL Calculation, 0300X-CA-V0056, Rev. 0, Washington Closure Hanford, Richland, Washington.

CERCLA = Comprehensive Environmental Response, Compensation, and Liability Act of 1980

COC = contaminant of concern

$\mathrm{MCL}$ = maximum contaminant level (drinking water standard)

RAG = remedial action goal

UCL $\quad=$ upper confidence limit
} 


\section{Table ES-2. Summary of Cleanup Verification Results for the 300-8 Waste Site - Unrestricted Land Use.}

\begin{tabular}{|c|c|c|c|}
\hline $\begin{array}{l}\text { Regulatory } \\
\text { Requirement }\end{array}$ & Remedial Action Goals & Results & $\begin{array}{l}\text { Remedial } \\
\text { Action } \\
\text { Objectives } \\
\text { Attained? }\end{array}$ \\
\hline $\begin{array}{l}\text { Direct Exposure - } \\
\text { Radionuclides }\end{array}$ & $\begin{array}{l}\text { Attain } 15 \mathrm{mrem} / \mathrm{yr} \text { dose rate above } \\
\text { background over } 1,000 \text { years. Attain } \\
\text { the CERCLA risk range of } 10^{-4} \text { to } \\
10^{-6} \text {. }\end{array}$ & $\begin{array}{l}\text { No radionuclide COCs were detected } \\
\text { above background levels. }\end{array}$ & Yes \\
\hline $\begin{array}{l}\text { Direct Exposure - } \\
\text { Nonradionuclides }\end{array}$ & Attain individual COC RAGs. & $\begin{array}{l}\text { All individual COC concentrations are } \\
\text { below the RAGs. }\end{array}$ & Yes \\
\hline \multirow{4}{*}{$\begin{array}{l}\text { Meet } \\
\text { Nonradionuclide Risk } \\
\text { Requirements }\end{array}$} & $\begin{array}{l}\text { Hazard quotient of }<1 \text { for } \\
\text { noncarcinogens. }\end{array}$ & \multirow{2}{*}{$\begin{array}{l}\text { Hazard quotients were not calculated } \\
\text { because concentrations of the only } \\
\text { nonradionuclide COC (beryllium) were } \\
\text { below statistical background levels. }\end{array}$} & \multirow{4}{*}{ Yes } \\
\hline & $\begin{array}{l}\text { Cumulative hazard quotient of }<1 \text { for } \\
\text { noncarcinogens. }\end{array}$ & & \\
\hline & $\begin{array}{l}\text { Excess cancer risk of }<1 \times 10^{-6} \text { for } \\
\text { individual carcinogens. }\end{array}$ & \multirow{2}{*}{$\begin{array}{l}\text { Excess cancer risks were not } \\
\text { calculated because concentrations of } \\
\text { the only nonradionuclide COC } \\
\text { (beryllium) were below statistical } \\
\text { background levels. }\end{array}$} & \\
\hline & $\begin{array}{l}\text { Attain a total excess cancer risk of } \\
<1 \times 10^{-5} \text { for carcinogens. }\end{array}$ & & \\
\hline \multirow{4}{*}{$\begin{array}{l}\text { Groundwater/River } \\
\text { Protection - } \\
\text { Radionuclides }\end{array}$} & $\begin{array}{l}\text { Attain single-COC groundwater and } \\
\text { river protection RAGs. }\end{array}$ & $\begin{array}{l}\text { All single-COC groundwater and river } \\
\text { RAGs have been attained. }\end{array}$ & \multirow{4}{*}{ Yes } \\
\hline & $\begin{array}{l}\text { Attain National Primary Drinking } \\
\text { Water Standards: } 4 \text { mrem/yr } \\
\text { (beta/gamma) dose rate to target } \\
\text { receptor/organs. }\end{array}$ & $\begin{array}{l}\text { No beta/gamma-emitting COCs were } \\
\text { identified for this site. }\end{array}$ & \\
\hline & $\begin{array}{l}\text { Meet drinking water standards for } \\
\text { nonuranium alpha emitters: the } \\
\text { more stringent of the } 15 \mathrm{pCi} / \mathrm{L} \mathrm{MCL} \\
\text { or } 1 / 25^{\text {th }} \text { of the derived concentration } \\
\text { guide per DOE Order } 5400.5 .^{\mathrm{b}}\end{array}$ & $\begin{array}{l}\text { No nonuranium alpha-emitting COCs } \\
\text { were identified for this site. }\end{array}$ & \\
\hline & $\begin{array}{l}\text { Meet total uranium standard of } \\
21.2 \mathrm{pCi} / \mathrm{L} .\end{array}$ & $\begin{array}{l}\text { Uranitum statistical values are below } \\
\text { background levels for this site. }\end{array}$ & \\
\hline $\begin{array}{l}\text { Groundwater/River } \\
\text { Protection - } \\
\text { Nonradionuclides }\end{array}$ & $\begin{array}{l}\text { Attain individual nonradionuclide } \\
\text { groundwater and river cleanup } \\
\text { requirements. }\end{array}$ & $\begin{array}{l}\text { All the groundwater and river RAGs } \\
\text { have been attained. }\end{array}$ & Yes \\
\hline $\begin{array}{l}\text { Supporting } \\
\text { Information }\end{array}$ & \multicolumn{3}{|c|}{ 300-8 Cleanup verification $95 \%$ UCL Calculation (Appendix C). } \\
\hline \multicolumn{4}{|c|}{ 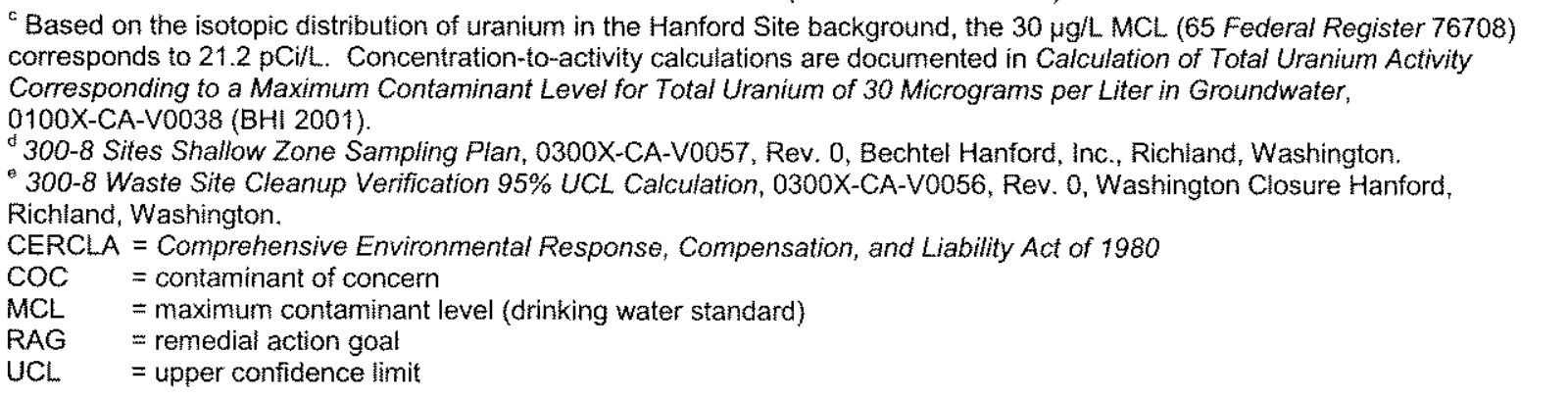 } \\
\hline
\end{tabular}


CVP-2005-00007

Rev. 0

\section{Attachment ES-1 \\ Waste Site Reclassification Form}

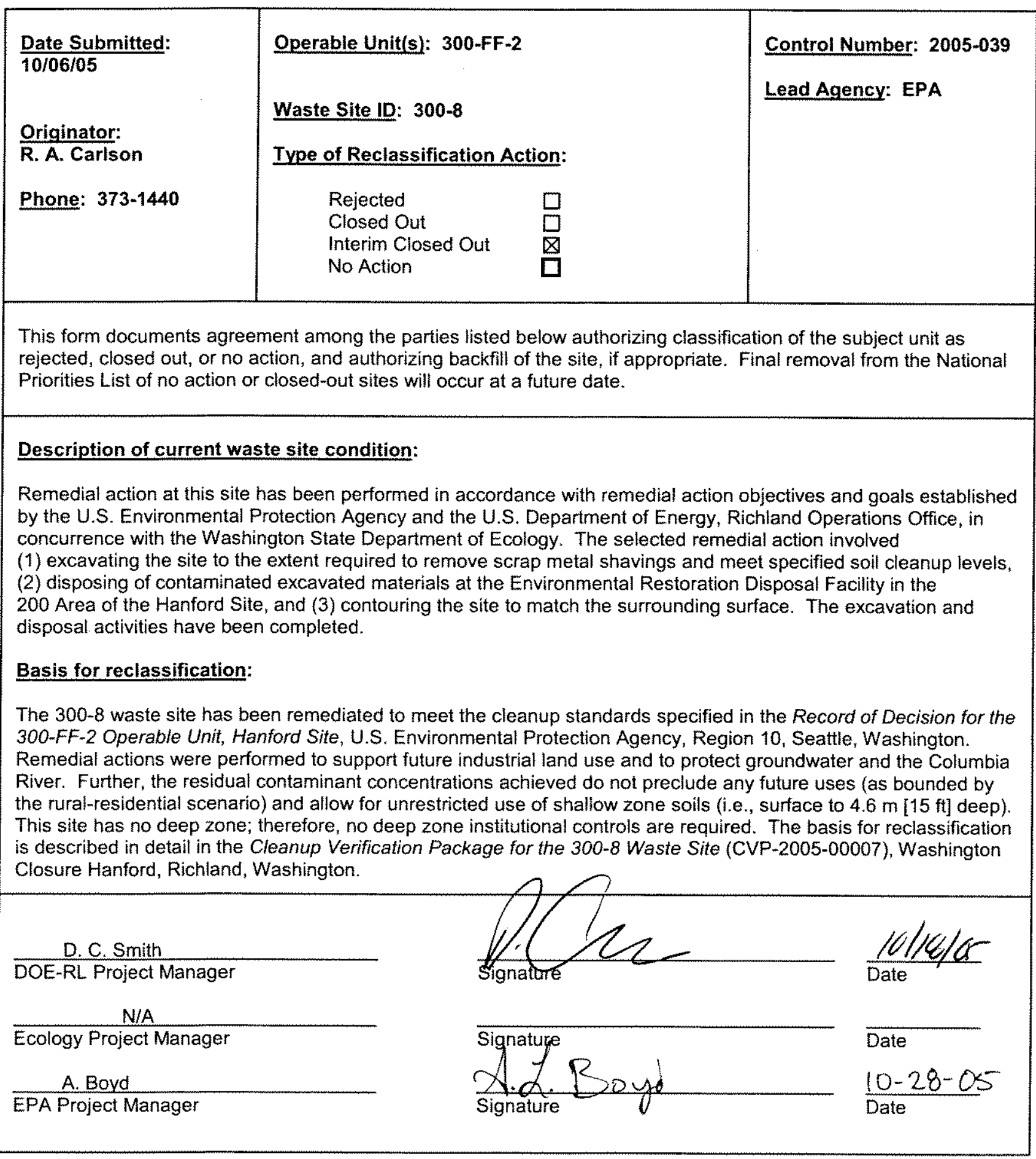


CVP-2005-00007

Rev. 0

ES-6 


\section{CONTENTS}

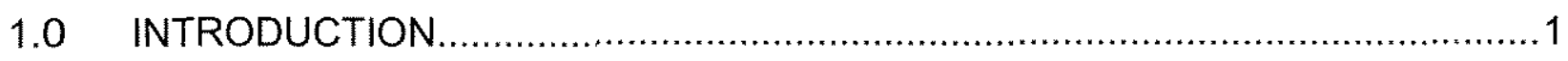

2.0 SITE DESCRIPTION AND SUPPORTING INFORMATION …........................

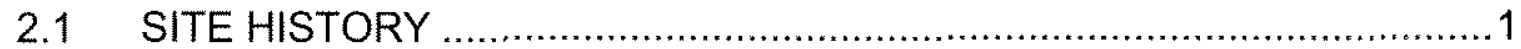

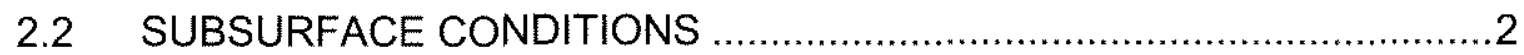

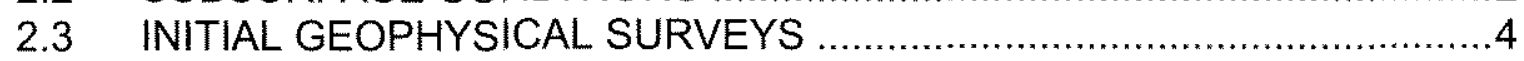

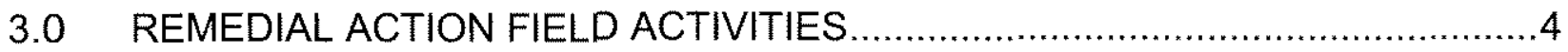

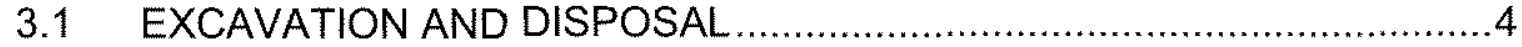

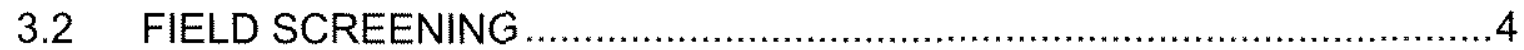

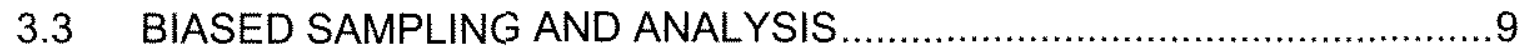

3.4 CLEANUP VERIFICATION SAMPLING AND ANALYSIS .........................

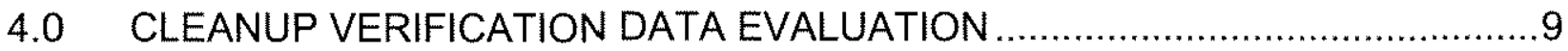

4.1 DATA QUALITY ASSESSMENT PROCESS ...................................10

4.2 CONTAMINANTS OF CONCERN 95\% UPPER CONFIDENCE LIMIT ...10

4.3 SITE-SPECIFIC CLEANUP VERIFICATION MODEL .......................11

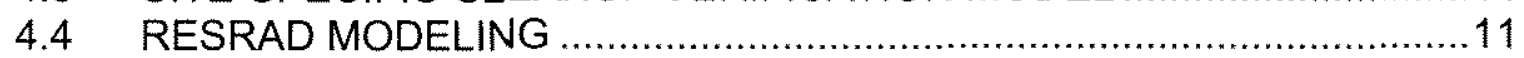

5.0 EVALUATION OF REMEDIAL ACTION GOAL ATTAINMENT FOR

INDUSTRIAL LAND USE ......................................................................

5.1 DIRECT EXPOSURE SOIL REMEDIAL ACTION GOALS ATTAINED ....12

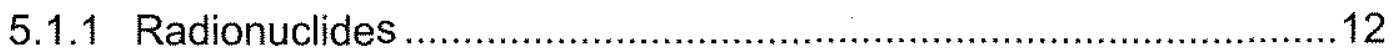

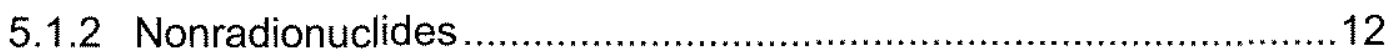

5.2 GROUNDWATER REMEDIAL ACTION GOALS ATTAINED .................13

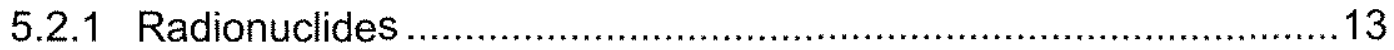

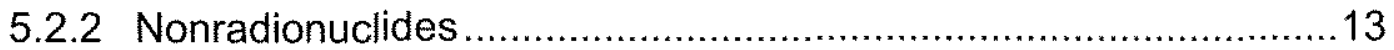

5.3 COLUMBIA RIVER REMEDIAL ACTION GOALS ATTAINED ...............13

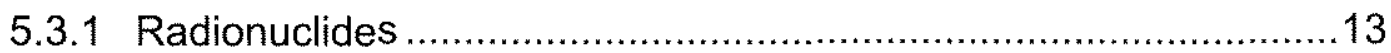

5.3.2 Nonradionuclides ...............................................................13

5.4 WAC 173-340 THREE-PART TEST FOR NONRADIONUCLIDES ..........14

6.0 EVALUATION OF REMEDIAL ACTION GOAL ATTAINMENT FOR

UNRESTRICTED LAND USE ................................................................. 14

6.1 DIRECT EXPOSURE SOIL REMEDIAL ACTION GOALS ATTAINED ...15

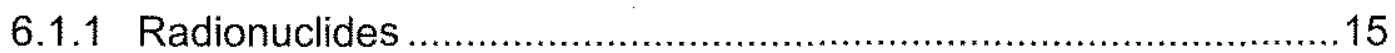

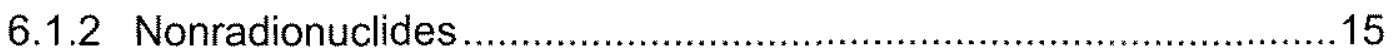

6.2 GROUNDWATER REMEDIAL ACTION GOALS ATTAINED ..................16

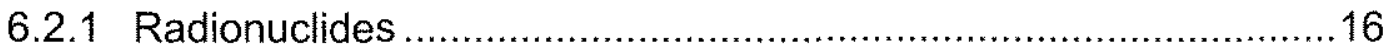

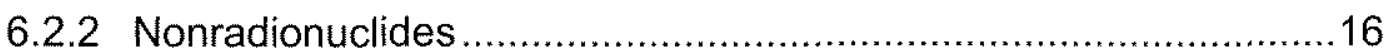

6.3 COLUMBIA RIVER REMEDIAL ACTION GOALS ATTAINED ................16

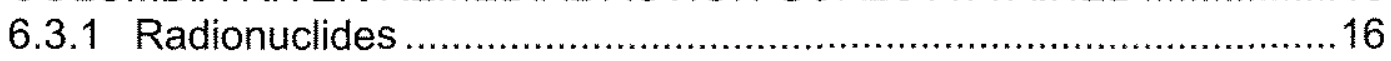

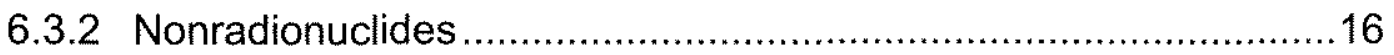




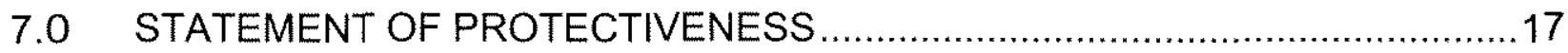

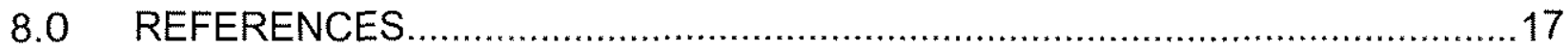

\section{APPENDICES}
A SUMMARY OF VERIFICATION SOIL SAMPLING AND ANALYTICAL RESULTS $A-i$
B DATA QUALITY ASSESSMENT FOR THE 300-8 WASTE SITE .................. B-i
C CALCULATION BRIEF EXCERPTS $C-i$

\section{FIGURES}

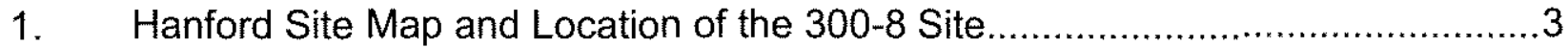

2. Locations of Test Plots for Geophysical Verification Surveys. .............................5

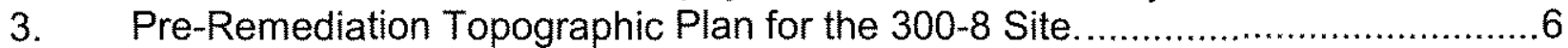

4. Post-Remediation Topographic Plan for the 300-8 Site .................................

5. Radiological Mapping Survey Results for the $300-8$ Site ............................... 8

\section{TABLES}

1. Summary of Remedial Action Goals - Industrial Land Use ................................2

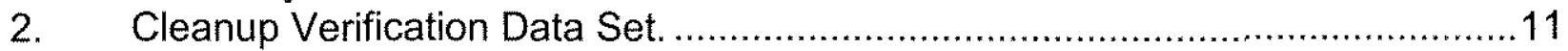

3. Attainment of Nonradionuclide Direct Exposure Standards Industrial Land Use.

4. Attainment of Nonradionuclide Direct Exposure Standards Unrestricted Land Use. 


\section{ACRONYMS AND ABBREVIATIONS}

$\begin{array}{ll}\text { COC } & \text { contaminant of concern } \\ \text { DQA } & \text { data quality assessment } \\ \text { ERDF } & \text { Environmental Restoration Disposal Facility } \\ \text { ESD } & \text { explanation of significant differences } \\ \text { RAG } & \text { remedial action goal } \\ \text { RAO } & \text { remedial action objective } \\ \text { RDR/RAWP } & \text { remedial design report/remedial action work plan } \\ \text { RESRAD } & \text { RESidual RADioactivity dose assessment model } \\ \text { ROD } & \text { record of decision } \\ \text { SAP } & \text { sampling and analysis plan } \\ \text { UCL } & \text { upper confidence limit } \\ \text { WAC } & \text { Washington Administrative Code } \\ \text { WCH } & \text { Washington Closure Hanford }\end{array}$


CVP-2005-00007

Rev. 0 


\subsection{INTRODUCTION}

The purpose of this cleanup verification package is to document that the 300-8 waste site was remediated in accordance with the Record of Decision for the 300-FF-2 Operable Unit, Hanford Site (ROD) (EPA 2001). Remedial action objectives (RAOs) and remedial action goals (RAGs) for the 300-8 site are documented in the ROD (EPA 2001) and the Remedial Design Report/Remedial Action Work Plan for the 300 Area (RDR/RAWP) (DOE-RL 2004b). The ROD provides the U.S. Department of Energy, Richland Operations Office the authority, guidance, and objectives to conduct this remedial action.

The preferred remedy specified in the ROD (EPA 2001) and conducted for the 300-8 site included (1) excavating the site to the extent required to remove scrap metal shavings and meet specified soil cleanup levels, (2) disposing of contaminated excavated materials at the Environmental Restoration Disposal Facility (ERDF) at the 200 Areas of the Hanford Site, and (3) contouring the site to match surrounding grade elevation. Excavation was driven by RAOs for direct exposure, protection of groundwater, and protection of the Columbia River. For the respective points of compliance, RAGs, summarized in Table 1, were established for the radionuclide and nonradionuclide contaminants of concern (COCs) in the RDR/RAWP (DOE-RL 2004b). Preliminary waste site contaminants of potential concern were identified in the 300 Area Remedial Action Sampling and Analysis Plan (SAP) (DOE-RL 2004a). Following excavation of the site, final COCs were identified in the Closeout Plan for Waste Site 300-8 (WCH 2005b) and are listed in Table 1.

\subsection{SITE DESCRIPTION AND SUPPORTING INFORMATION}

\subsection{SITE HISTORY}

The 300-8 waste site is located in the 300-FF-2 Operable Unit of the 300 Area, along the railroad line north of the 300 Area and adjacent to the 618-8 and 618-3 Burial Grounds (Figure 1). Beginning in 1962, the area adjacent to the railroad line was used to stage scrap metal from the 300 Area in support of a program to recycle aluminum. Some of the metal was contaminated with low levels of uranium and beryllium from 300 Area operations. Scrap metal was staged in the area until sufficient quantities were available to solicit bids from offsite salvage vendors. Sold scrap metal was loaded into open rail cars with clamshell buckets. This process of staging and loading the scrap metal scattered the material over an area greater than $30,000 \mathrm{~m}^{2}\left(321,000 \mathrm{ft}^{2}\right)$. Geophysical surveys of the area performed as part of the 300-FF-2 Operable Unit limited field investigation (DOE-RL 1997) suggested that the scrap metal was dispersed in the top $0.3 \mathrm{~m}(1 \mathrm{ft})$ of soil. During remediation, it was determined that scrap metal was predominantly in the top $0.6 \mathrm{~m}(2 \mathrm{ft})$ of soil. The posted soil contamination areas are separated by unposted dirt roads that were cleared of contamination and a railroad 
line. The railroad line is excluded from the $300-8$ site and has not been investigated because it may have future potential uses in support of ongoing or new industrial activities in the 300 Area.

Table 1. Summary of Remedial Action Goals - Industrial Land Use.

\begin{tabular}{|c|c|c|c|}
\hline cocs & $\begin{array}{c}\text { Direct Exposure } \\
\text { RAG } \\
\text { (pCi/g) }\end{array}$ & $\begin{array}{c}\text { Soil RAG for } \\
\text { Groundwater Protection } \\
(\mathrm{pCl} / \mathrm{g})\end{array}$ & $\begin{array}{l}\text { Soil RAG for Columbia } \\
\text { River Protection } \\
\text { (pCi/g) }\end{array}$ \\
\hline \multicolumn{4}{|c|}{ Radionuclides } \\
\hline Uranium (total) & $350^{\mathrm{a}}$ & $267^{b}$ & $267^{b}$ \\
\hline $\operatorname{cocs}$ & $\begin{array}{c}\text { Direct Exposure } \\
\text { RAG } \\
\text { (mg/kg) }\end{array}$ & $\begin{array}{c}\text { Soil RAG for } \\
\text { Groundwater Protection } \\
(\mathrm{mg} / \mathrm{kg})\end{array}$ & $\begin{array}{l}\text { Soil RAG for Columbia } \\
\text { River Protection } \\
(\mathrm{mg} / \mathrm{kg})\end{array}$ \\
\hline \multicolumn{4}{|c|}{ Nonradionuclides } \\
\hline Beryllium & $104^{c}$ & $N A^{d}$ & $N A^{d}$ \\
\hline
\end{tabular}

a Listed value is equal to a $15 \mathrm{mrem} / \mathrm{yr}$ dose for the industrial exposure scenario (DOE-RL 2004b)

${ }^{b}$ Value calculated using RESRAD, based on the generic site model (DOE-RL 2004b).

"Value calculated based on the inhalation exposure pathway per Washington Administrative Code 173-340-750(4)(b)(ii)(A) or (B).

${ }^{\circ}$ RESRAD modeling predicts the constituent will not reach groundwater within 1,000 years based on a generic site profile (DOE-RL 2004b).

COC = contaminant of concern

NA $=$ not applicable

RAG = remedial action goal

RESRAD = RESidual RADioactivity (dose assessment model)

WAC $=$ Washington Administrative Code

\subsection{SUBSURFACE CONDITIONS}

The soil column (vadose zone) underlying the waste site and extending to groundwater consists of the Hanford and Ringold Formations. The shallower Hanford Formation consists predominantly of medium-dense to dense sand and gravel, with varying amounts of silt and cobble. The underlying Ringold Formation consists of dense, wellcemented gravels with sand and silt interbedding. The Hanford/Ringold contact is approximately 9 to $21 \mathrm{~m}$ (30 to $69 \mathrm{ft}$ ) below the surface grade level.

The long-term groundwater level beneath the site is estimated at El. $104.6 \mathrm{~m}$ (North American Vertical Datum of 1988) based on information from local groundwater wells. Groundwater levels are influenced by the nearby Columbia River and other factors such as atmospheric pressure. The depth to groundwater is approximately $12.5 \mathrm{~m}(41 \mathrm{ft})$ beneath the maximum depth of soil removal at the 300-8 waste site. 
Figure 1. Hanford Site Map and Location of the 300-8 Site.

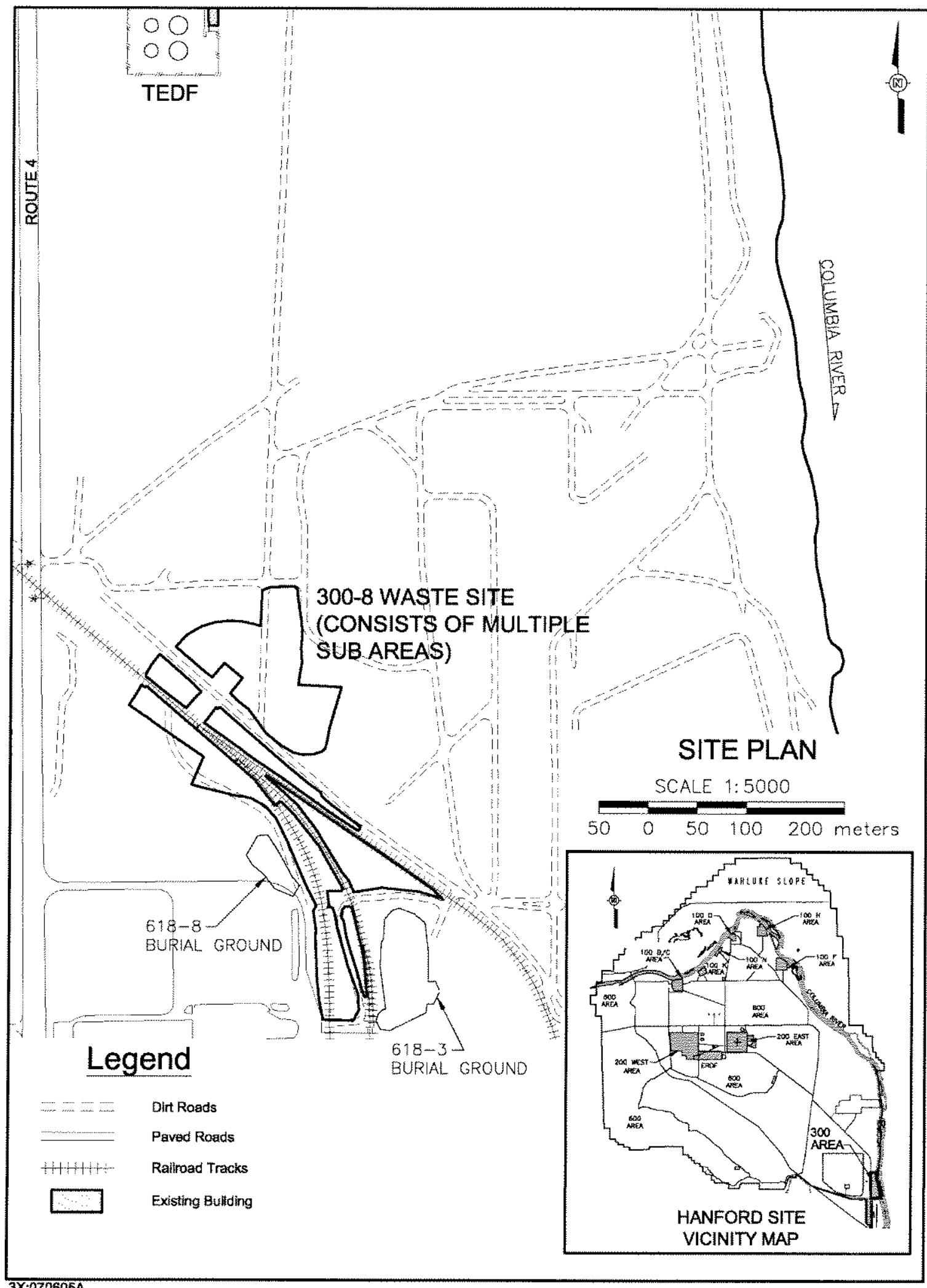




\subsection{INITIAL GEOPHYSICAL SURVEYS}

Geophysical surveys were conducted at the $300-8$ waste site prior to remediation activities to evaluate the effectiveness of survey equipment and to assess the changing density of metal fragments across the site. Both metal detectors evaluated (an EM-61 High Sensitivity Metal Detector and a Fisher 1270 Metal Detector) were determined to

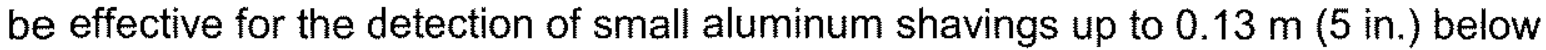
ground surface (WCH 2005a). In general, significantly more aluminum shavings were identified north of the haul road than between the road and the railroad tracks. Additional detail regarding the distribution of metallic debris prior to remediation activities is provided in $\mathrm{WCH}$ (2005a).

\subsection{REMEDIAL ACTION FIELD ACTIVITIES}

\subsection{EXCAVATION AND DISPOSAL}

Remedial action at the 300-8 site was conducted from December 2004 to May 2005. Excavation of the site included the removal of small quantities of miscellaneous metal construction-type debris (e.g., nuts, bolts), aluminum metal shavings, and soil. No indications of liquid waste disposal or land disposal restricted materials were observed during excavation.

Initially, material within the site boundaries was removed to a depth of $0.3 \mathrm{~m}(1 \mathrm{ft})$. Following excavation, geophysical surveys and ground-truthing excavations indicated that significant quantities of metal shavings, on the order of one to a few per square

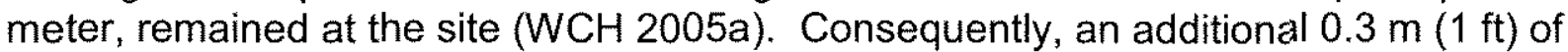
material was removed from the entire area. Following this excavation, additional geophysical surveys were performed at thirty-five randomly located 3- by 3-m (10- by 10-ft) test areas within the 300-8 waste site boundaries (Figure 2). Within the $324 \mathrm{~m}^{2}$ $\left(3,488 \mathrm{ft}^{2}\right)$ surveyed, fewer than 10 discrete pieces of metallic debris were detected (WCH 2005a). Based on these results and ground-truthing excavations, it was concluded that remediation was complete.

Approximately 39,750 metric tons $(43,820$ U.S. tons) of material was removed for disposal at the ERDF. Pre- and post-remediation topographic civil survey results for the 300-8 waste site are depicted in Figures 3 and 4.

\subsection{FIELD SCREENING}

Radiological surveys were performed in May 2005 after excavation operations were complete at the 300-8 waste site to provide an initial assessment of attainment of radiological cleanup levels. The survey methodology was based on an assumption of 
Figure 2. Locations of Test Plots for Geophysical Verification Surveys.

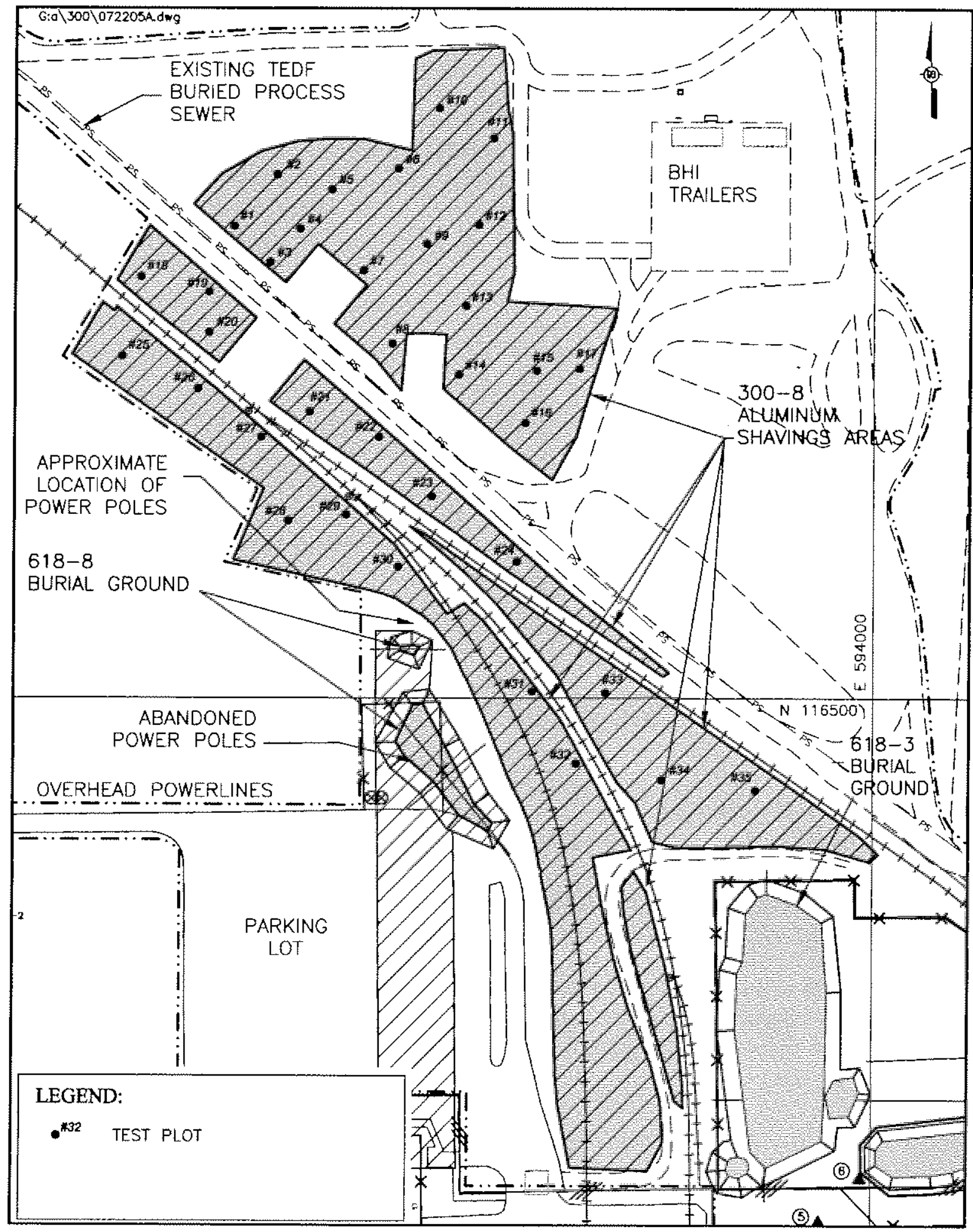


Figure 3. Pre-Remediation Topographic Plan for the 300-8 Site.

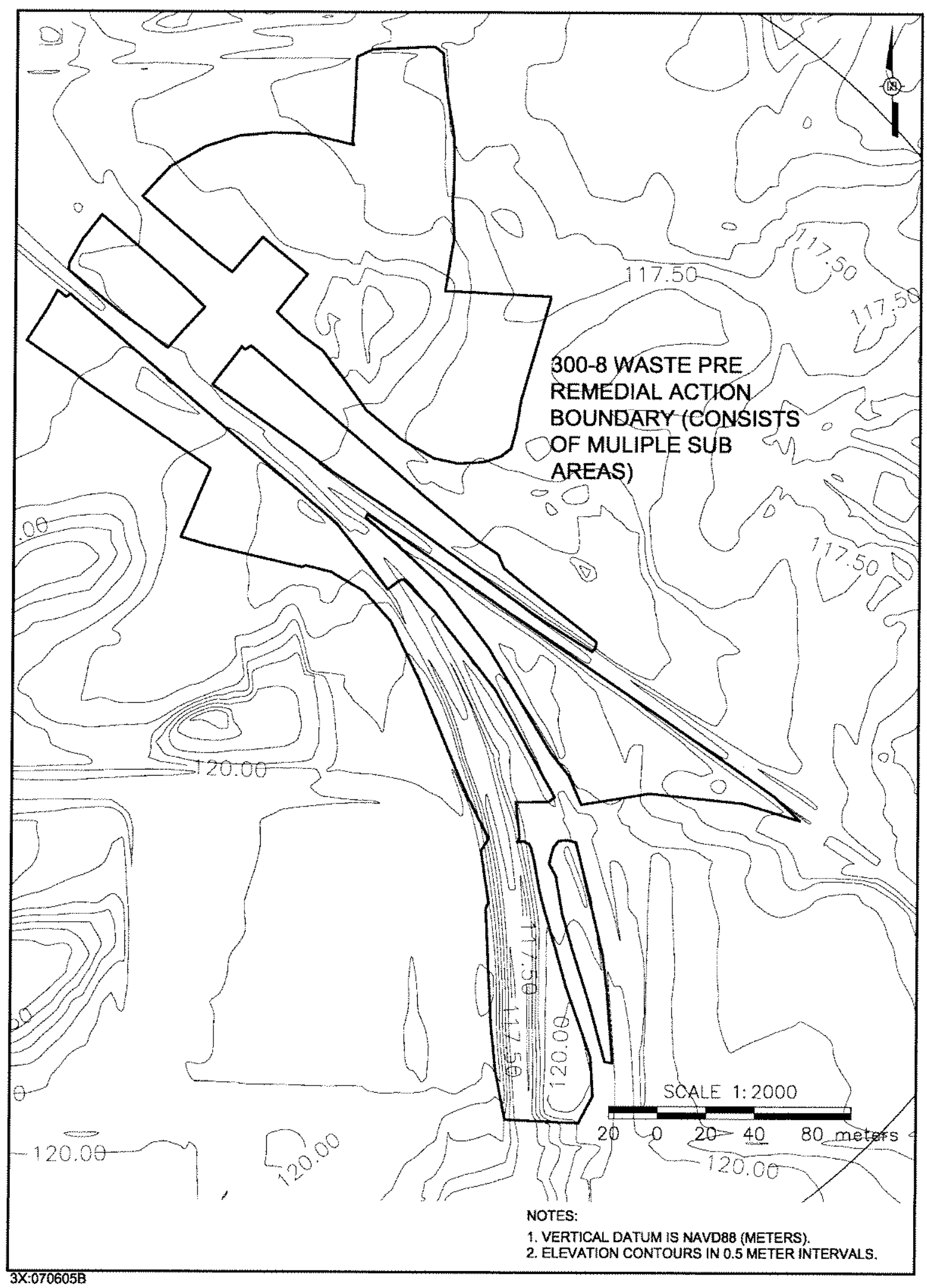


Figure 4. Post-Remediation Topographic Plan for the 300-8 Site.

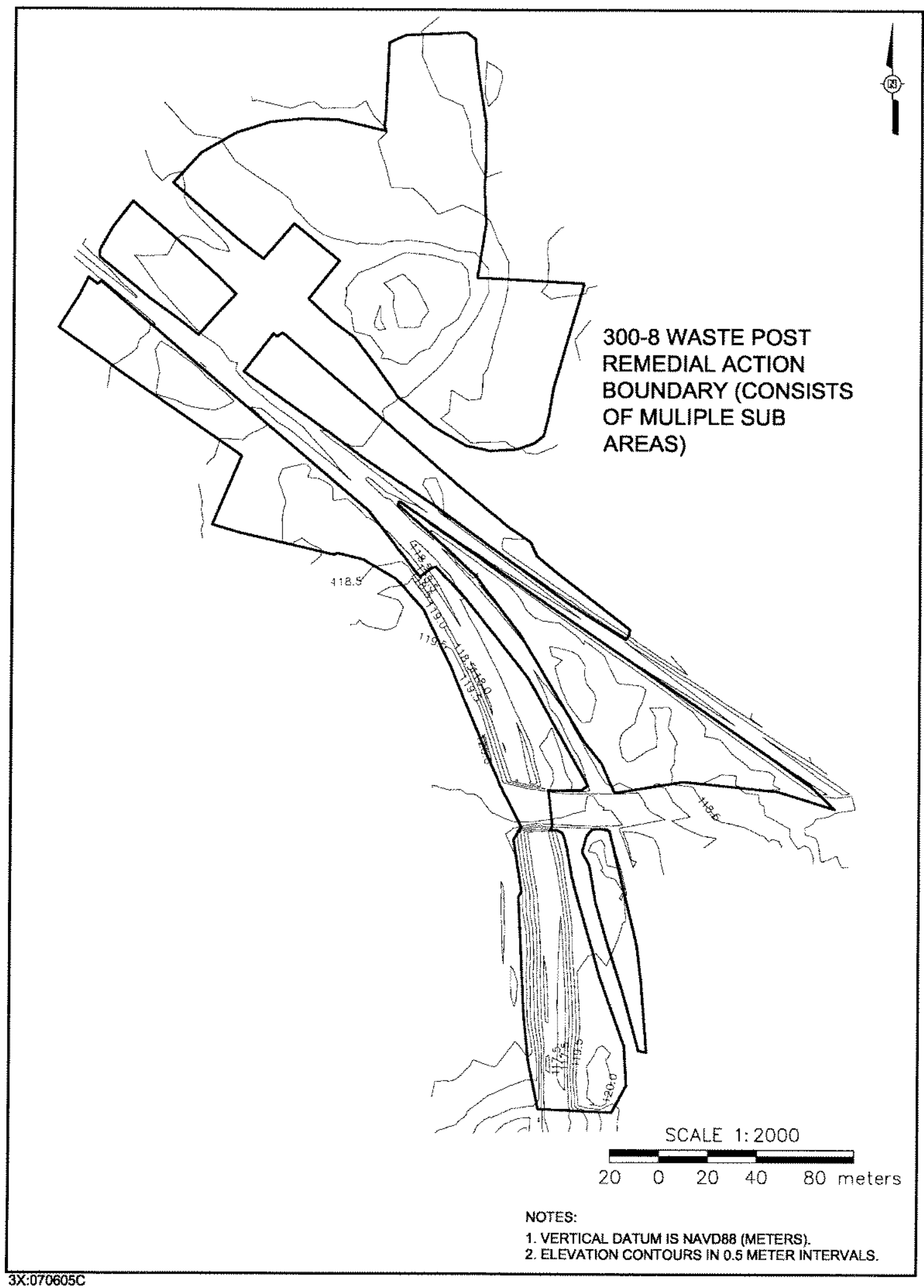


Figure 5. Radiological Mapping Survey Results for the 300-8 Site.

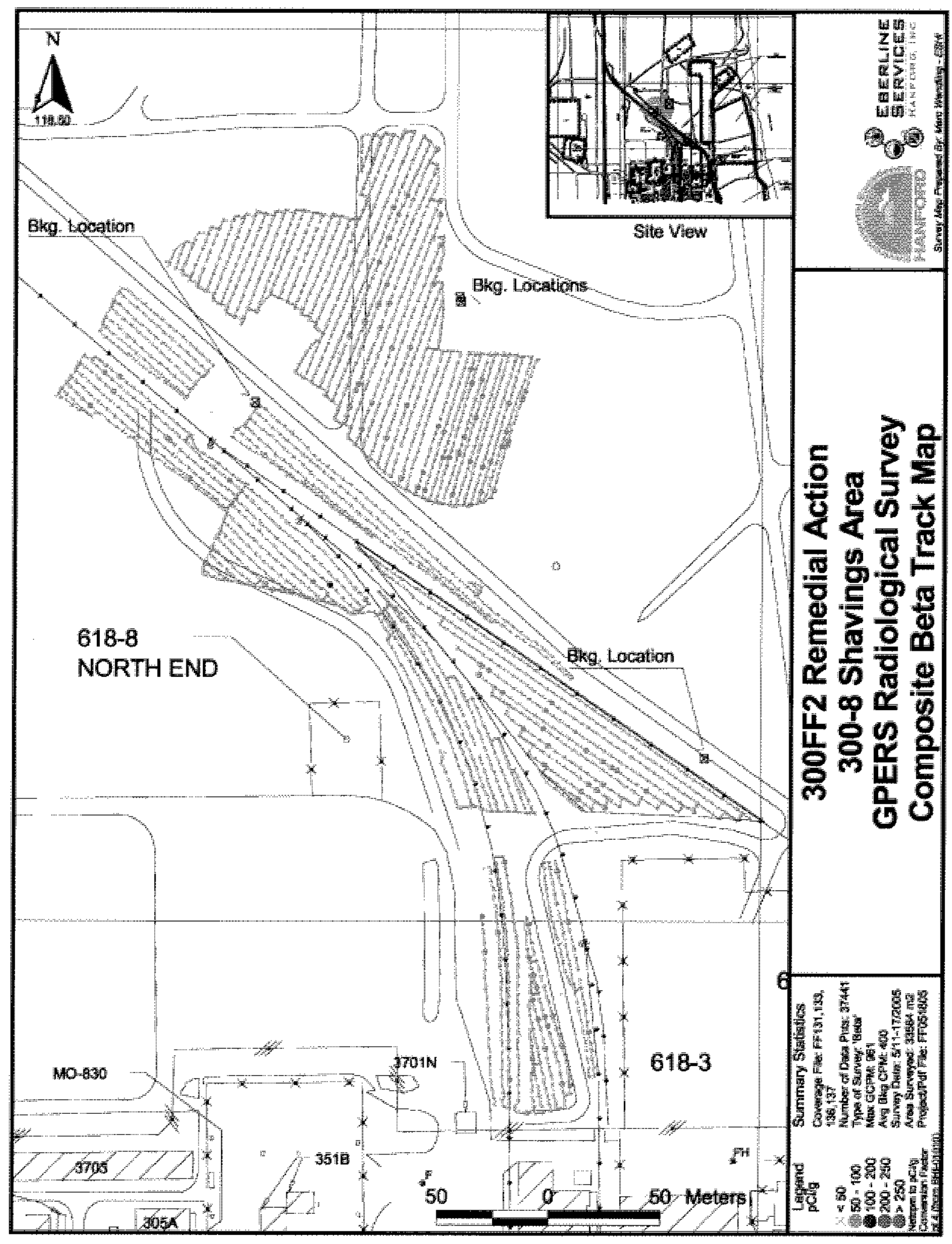




\section{CALCULATION COVER SHEET}

Project Title:

Area

Discipline

Subject

Computer Progran
300 Area Remedial Action

300

Environmental

Excel *alc. No
Calculation

Job No. $0300 \mathrm{X}-\mathrm{CA}-\mathrm{V} 0056$

Program No. Excel 2003

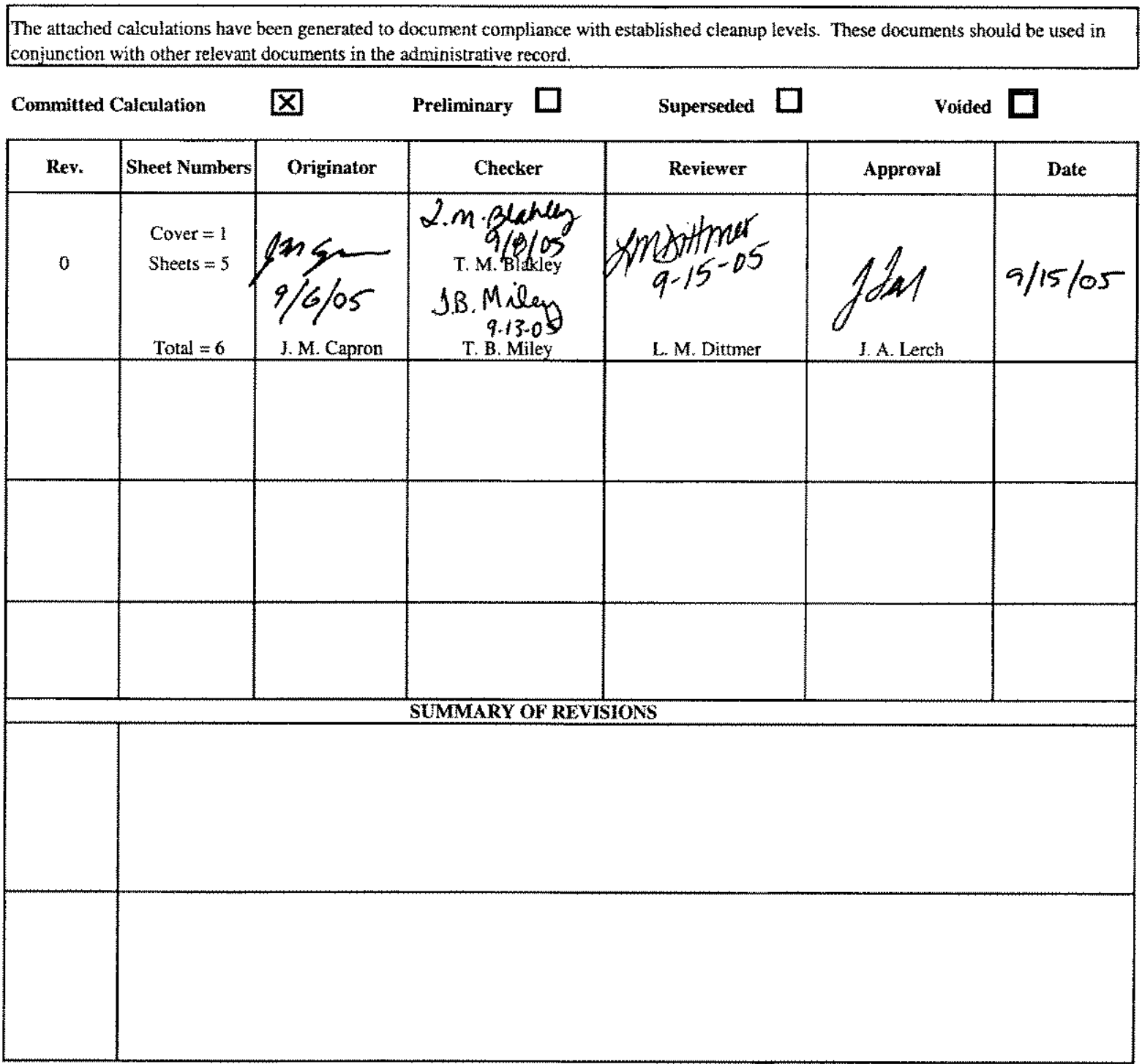

* Obtain calc no. from DIS

DE01437.03 (12709/2004) 


\section{Wastingtom Closure Hantord

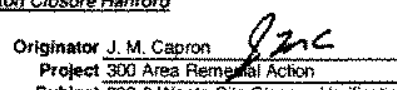 \\ CALCULATION SHEET \\ Date 09/0sios Job No. $\$ 4655$}

Calc. Na. 0300X-CA-Y0056

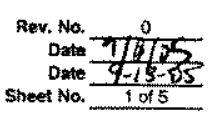

\section{Purpose:}

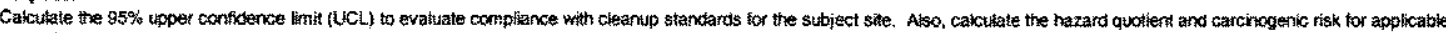

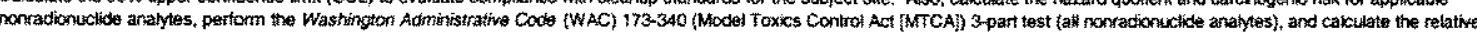
percent cifiterence \{ $P$ PPD) for each contaminant of concern (COC)

\section{Table of Contents:}

Streets 1 to 2-Cakuiation Sheet Surnmary

Sheet 3 . Carcusation Sheet Shatlow Zone

5. Catculation Stregt Split Duplicate Analysis

Sheet 5 - Ecokggy Software (MTCAStai) fiesultis

Given:Roturanten:

t) Sample Resutus

2) Lookup values, background values, and temedial action goats (RAGs) are taken from DOE-RL (1996), DOE-RL. (2001), the remediat design reportremedial action work pian (RDR/RAWP)

(DOE-FI.

$2004 \mathrm{~b})$, and Ecology (1996)

3) DOE-RL, 1996, Hanford Site Background: Part 2, Sol Background for Radionuclides, DOERt-96-12, Rov. 0, U.S. Depafment of Energy, Fichtand Operations Office,

Fichland, Wastington.

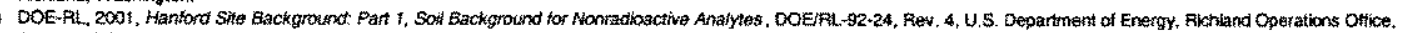

Aichiand, Washington.

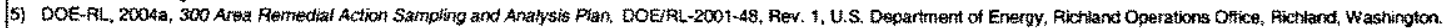

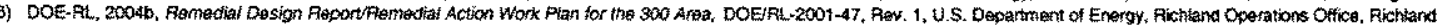
Washington.

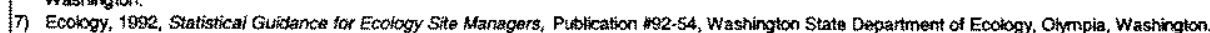

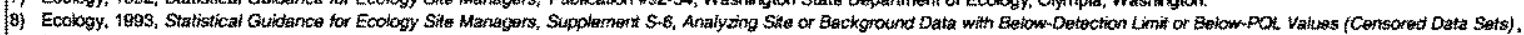

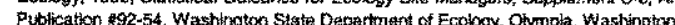

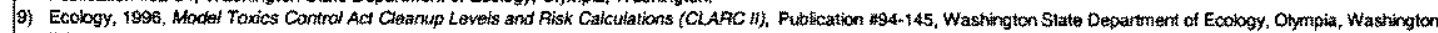

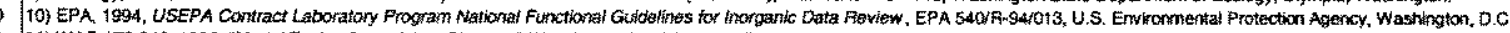

11) WAS IT

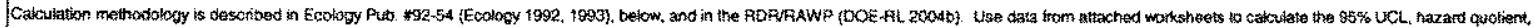

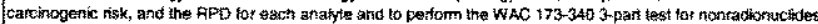

Catculition Deweriptition:

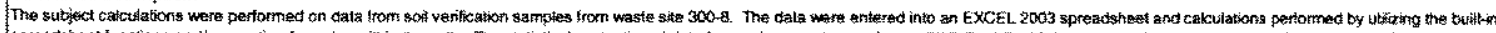

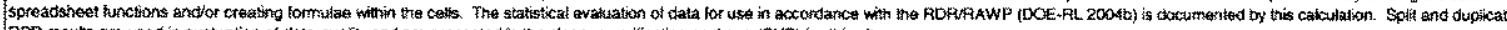

Methodelogy:

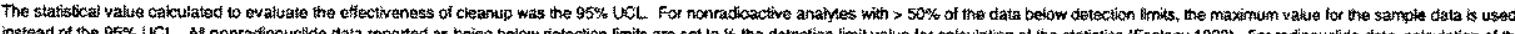

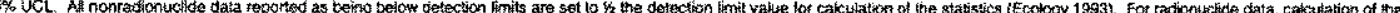

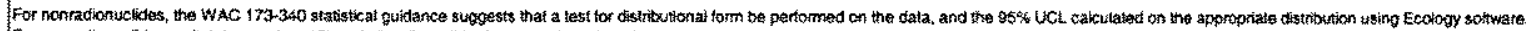

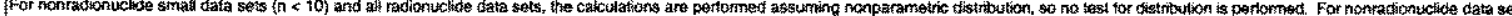

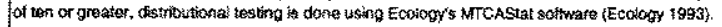

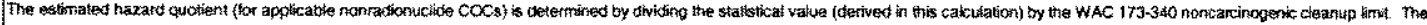

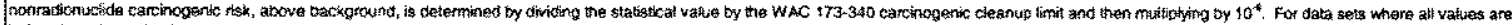
below datection of background levels, neither of these calculations are required.

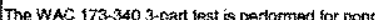

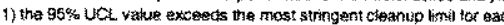

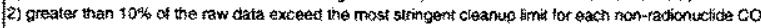

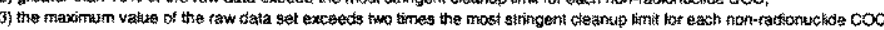

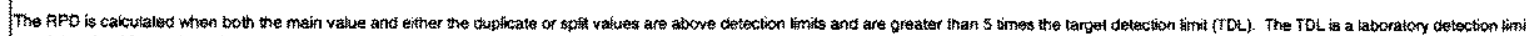

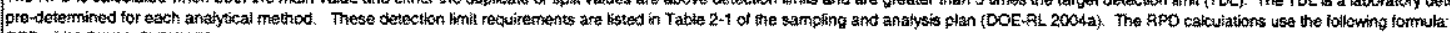
APD $=[M-S K(M+S+2)]^{*} 100$

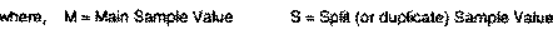

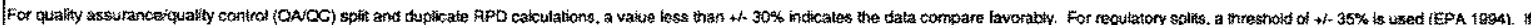

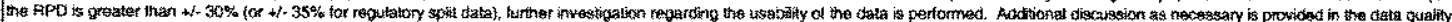
assessment section of the applicable CVP.

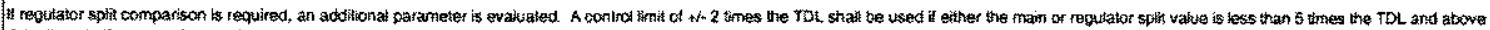

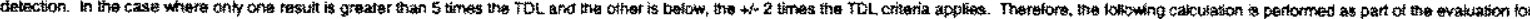

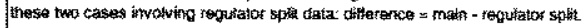

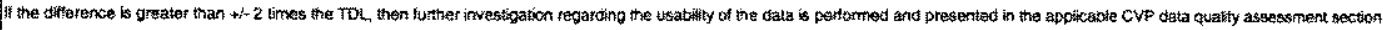

No regulatory spots satnoles were colloctiod tot the 300-8 site. 
CVP-2005-00007

Rev. 0

Washington Closure Hantord

CALCULATION SHEET

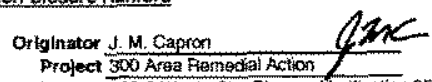

Date osicosios

subject 300.8 Waste Site Cleanup Verification $95 \%$ ucL Calculation

Dato $\frac{09065}{14655}$

Cate. No. $0300 \times-C A v$ Voos6

Checked T. M. Btakiley $\tan 3$

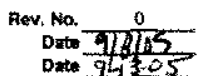

Checkad T. B. Mhey $\mathrm{BBM}$

Date 94305

Summary (continued)

1 Resutts:

2 The restuts presented in the summary tables that follow are for use in RESRAD doselrisk andifysis and the CVP for this site.

3

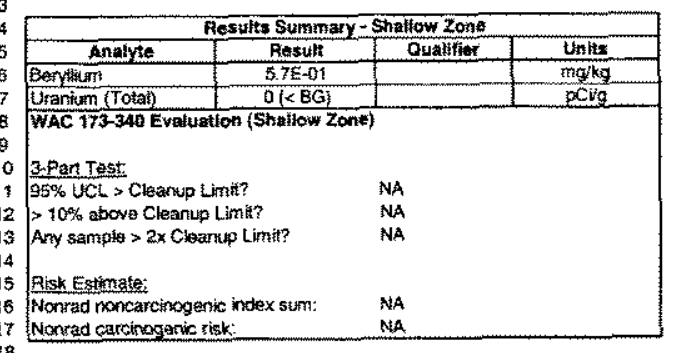

7 Nontad carcinoganic risk:

19 Roletive Percent Difference (APD)

20 Aesults (Shallow Zone)* CANOC Analyst:

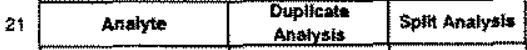

22 Eerylum

Uranium (Total)

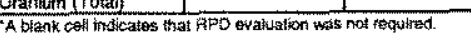

$25 B a=$ backoround

26 OAOC = Quality assurancelquality controd

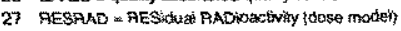

28 UCL * upper contidence linit

29 WAC = Washirgton Adrininistrativa Code 


\begin{tabular}{|c|c|c|c|c|c|c|c|c|}
\hline \\
\hline Wastingtons & & & & & & \multirow{4}{*}{\multicolumn{3}{|c|}{ 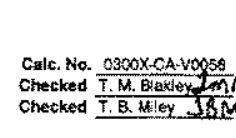 }} \\
\hline \multirow{2}{*}{\multicolumn{3}{|c|}{ 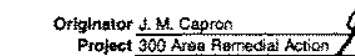 }} & & & & & & \\
\hline & & & Job Kio. & & 14655 & & & \\
\hline \multicolumn{6}{|c|}{ Subjecl 300. a Waste Sita Clearmp Verification $95 \%$ UCL Catcutation } & & & \\
\hline \multicolumn{9}{|c|}{ 300-8 Shatlow Zone Sampie Data } \\
\hline \multirow{2}{*}{ Sempiting } & \multirow{2}{*}{$\begin{array}{l}\text { HEIS } \\
\text { Number }\end{array}$} & \multirow{2}{*}{$\begin{array}{c}\text { Stmple } \\
\text { Oate }\end{array}$} & \multicolumn{3}{|c|}{ Eeryilium } & \multicolumn{3}{|c|}{ Uranium (Total) } \\
\hline & & & $\mathrm{mg} / \mathrm{kg}$ & 0 & POA & $\mathrm{pCug}$ & 0 & MoA \\
\hline Al & 103304 & 727272005 & A.7E-01 & & $9 E-03$ & $\frac{1,341 E+00}{1.00}$ & & $1.96-01$ \\
\hline $\begin{array}{l}\text { Duplisats of } \\
\text { J03VDa }\end{array}$ & э03VH & $7 / 27 / 2005$ & $6.05-01$ & & 9.E. 03 & $1.095 E+\infty 0$ & & $2.4 E-01$ \\
\hline$A_{2}^{2}$ & Jarvos & $72727 / 2005$ & 4.9E.01 & & 9.E-03 & $1,141 \mathrm{E}+\infty 0$ & & $1.8 \mathrm{E}-01$ \\
\hline $\mathrm{A}^{3}$ & Ja3y06 & $7 / 2712005$ & $4.98-01$ & & $9 \mathrm{E}-03$ & $1.145 E+\infty$ & & $2.0 E-0: 5$ \\
\hline A4 & SOSWD? & $7 / 2772005$ & $5.1 E-07$ & & $9 . E-03$ & $1.171 \mathrm{E}+\infty$ & & $9.9 E-0:$ \\
\hline B5 & $.003 v 08$ & 772770005 & $5.1 \mathrm{E}-0 \mathrm{~T}$ & & 1.E.02 & $1.449 \mathrm{E}+\infty$ & & 2.1En? \\
\hline$B$ & J03VD9 & $7 / 2720005$ & $5.4 E-01$ & & G.E-03 & $1.204 \mathrm{E}+50$ & & $1.8 \mathrm{E}-0.01$ \\
\hline 87 & JO3VFO & 772772005 & $5.3 E-01$ & & 9E.03 & $1.133 E+\infty 0$ & & $2.0 E-8 t$ \\
\hline as & Ja3vif & $7 / 2772005$ & $60 \mathrm{E}-01$ & & $9.0-03$ & $1.190 E+00$ & & $19 \mathrm{E}-01$ \\
\hline 6 & JOaVF 2 & 72282005 & $5.5 \mathrm{E}-01$ & & $9 . \mathrm{E}: 03$ & $1089 E+00$ & & $19 \mathrm{E}-91$ \\
\hline 010 & LOSVF3 & $7 / 282005$ & $5.5 E-01$ & & $9 \mathrm{E} 6 \mathrm{43}$ & $1.12+E+\infty$ & & 1.7t-01 \\
\hline Ci & NOSVF 4 & $728<2005$ & $5.7 \mathrm{E}-01$ & & $9 \mathrm{E}+03$ & $6.92 E-01$ & & T.GE-0t \\
\hline$c_{2}$ & NOSVE & 77282006 & 5.7501 & & $9.5-03$ & $2.081 E+00$ & & $1.0 E .01$ \\
\hline $\mathrm{D}^{3}$ & JO3VFE & $7828 / 2005$ & $55 E=01$ & & $9 . E=03$ & $1,363 E+\infty 0$ & & $2.0 E-01$ \\
\hline Da & $503 \mathrm{VF} 7$ & $3.28 / 2005$ & $5.2 E-01$ & & $9 . E .03$ & $3.775 E+100$ & & $1.96 \cdot 01$ \\
\hline DS & $303 \mathrm{VF}$ & $7 / 28 / 2005$ & $5,1 t=01$ & & G.E.03 & $1.646 E+00$ & & $\frac{1.9 E Q 1}{2.1 E 01}$ \\
\hline$D E$ & 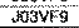 & 772822005 & $5.8 E=01$ & & G.E.03 & $8.950 \mathrm{E} \cdot 01$ & & $1.9 \mathrm{E}+01$ \\
\hline
\end{tabular}

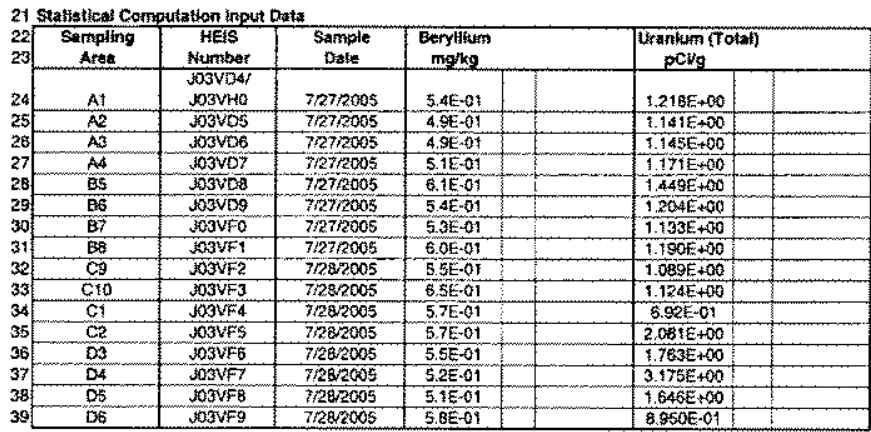

40 Statistical Computation:

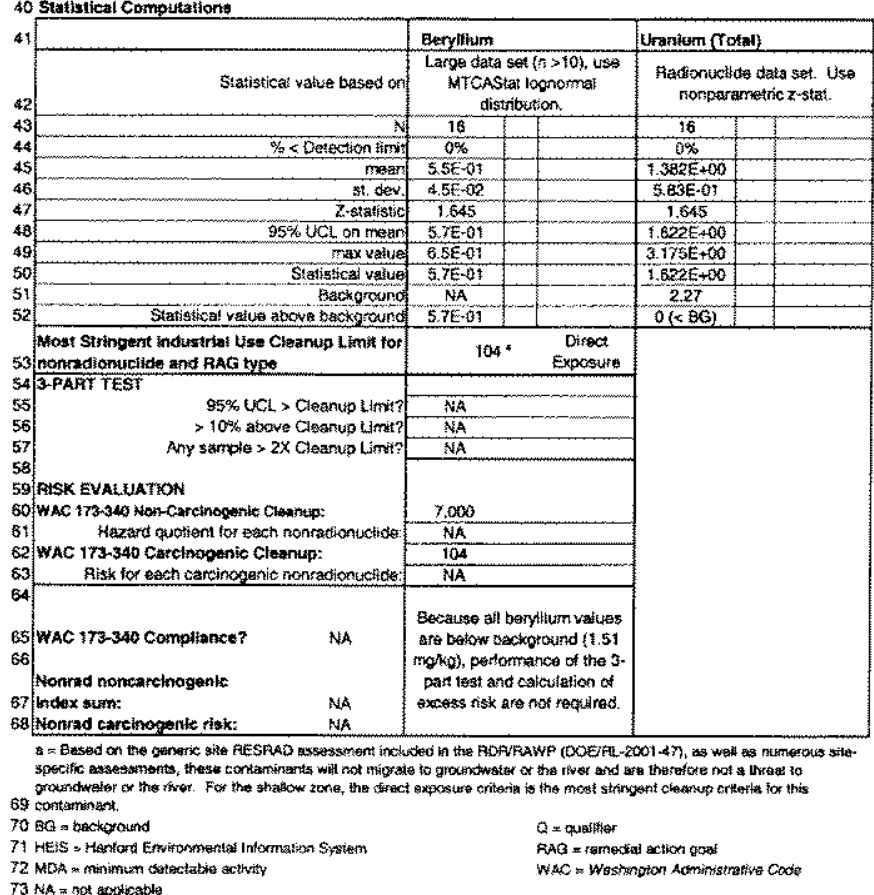

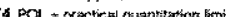




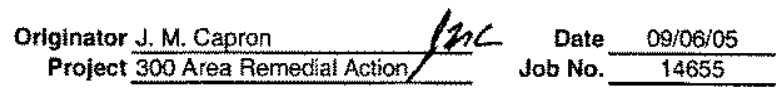

Subject 300-8 Waste Site Cleanup Verification 95\% UCL Calculation
Calc. No. 0300X-CA-V0055

Checked T.M. Blakley $2 \mathrm{mB}$

Checked T. B. Miley $10 M$

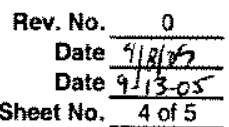

Split/Duplicate Analysis:

\begin{tabular}{|c|c|c|c|c|c|c|c|}
\hline \multirow{2}{*}{$\begin{array}{c}\text { Composite } \\
\text { Area }\end{array}$} & \multirow[b]{2}{*}{ HEIS Number } & \multicolumn{3}{|c|}{ Beryllium } & \multicolumn{3}{|c|}{ Uranium (Total) } \\
\hline & & $\mathrm{mg} / \mathrm{kg}$ & $\mathbf{a}$ & PQL & $\mathrm{pCl} / \mathrm{g}$ & $\mathrm{Q}$ & MDA \\
\hline A1 & J03VD4 & $4.7 E=01$ & & $9.0 \mathrm{E}-03$ & $1.341 E+00$ & & $1.9 \mathrm{E}-01$ \\
\hline $\begin{array}{c}\text { Duplicate of } \\
\text { J03VD4 }\end{array}$ & Jo3VHo & $6.0 \mathrm{E}-01$ & & $9.0 \mathrm{E}-03$ & $1.095 E+00$ & & $2.4 \mathrm{E}-01$ \\
\hline $\begin{array}{l}\text { Split of } \\
\text { Jo3VD4 }\end{array}$ & J03VH1 & 5.3E-01 & & $5.0 E_{m} 01$ & $1.487 E+\infty$ & & $1.17 \mathrm{E}-01$ \\
\hline
\end{tabular}

7 Shallow Zone Analysis:

\begin{tabular}{|c|c|c|c|c|}
\hline \multirow{3}{*}{8} & \multicolumn{2}{|r|}{$\mathrm{TDL}$} & 0.5 & 1 \\
\hline & \multirow{3}{*}{$\begin{array}{l}\text { Duplicate } \\
\text { Analysis }\end{array}$} & Both $>$ PQL/MDA? & Yes (continue) & Yes (continue) \\
\hline & & Both $>5 \times$ TDL? & No-Stop (acceptable) & No-Stop (acceptable) \\
\hline 0 & & $\mathrm{RPD}$ & & \\
\hline 1 & \multirow{3}{*}{ Split Artalysis } & Both >PQL/MDA? & Yes (continue) & Yes (continue) \\
\hline & & Both >5xTDI? & No-Stop (acceptable) & No-Stop (acceptable) \\
\hline 3 & & RPD & & \\
\hline
\end{tabular}

14 HEIS = Hanford Environmental Information System

$15 \mathrm{MDA}=$ mirimum detectable activity

$16 \mathrm{PQL}$ = practical quantitation timit

$17 \mathrm{Q}=$ qualifier

$18 \mathrm{RPO}=$ relative percent difference

19 TDL $=$ target detection limit 
CVP-2005-00007

Rev. 0

\section{Washington Closure Hanford}

CALCULATION SHEET

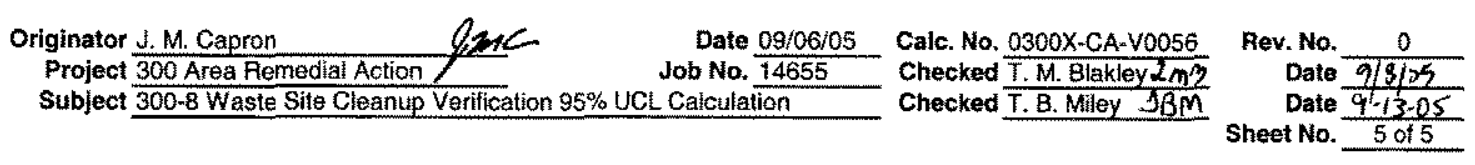

Ecology Software (MTCAStat) Results

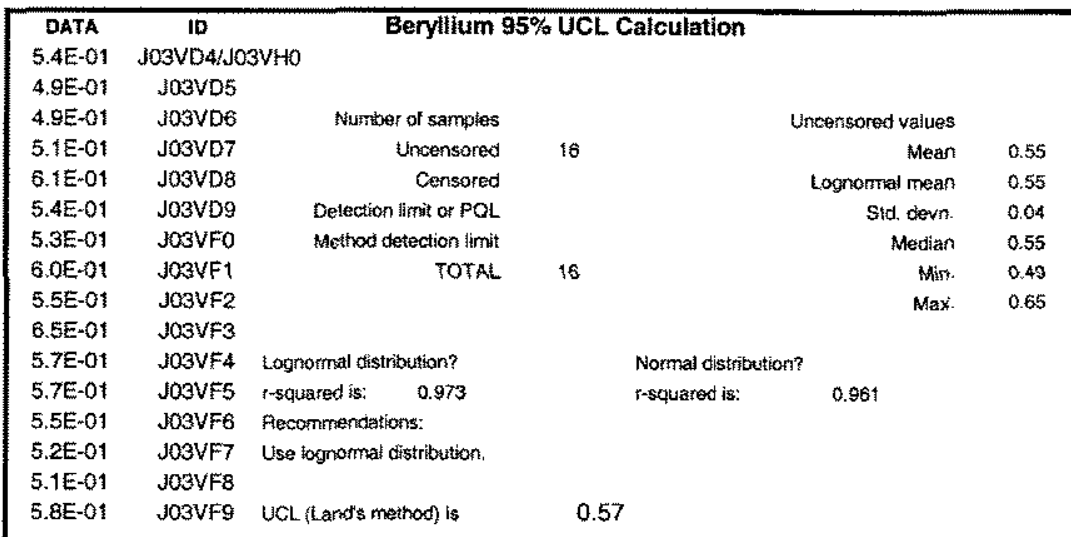




\section{DISTRIBUTION}

U.S. Department of Energy

Richland Operations Office

D. C. Smith (5) A3-04

DOE-RL Public Reading Room H2-53

Fluor Hanford, Inc.

J. P. Shearer (WIDS)

A0-21

Washington Closure Hanford

K. A. Anselm

H9-02

J. M. Capron

$\mathrm{H} 9-01$

R. A. Carlson

$\times 0-17$

S. W. Clark

H9-01

J. W. Darby

L6-06

L. A. Dietz

$\mathrm{H} 0-23$

L. M. Dittmer

H9-02

J. A. Lerch

$\mathrm{HO}-23$

J. E. Thomson

$\mathrm{HO}-23$

Records and Document Control

$\mathrm{HO}-30$

Hanford Technical Library

P8-55 
CVP-2005-00007

Rev. 0

Distr-2 


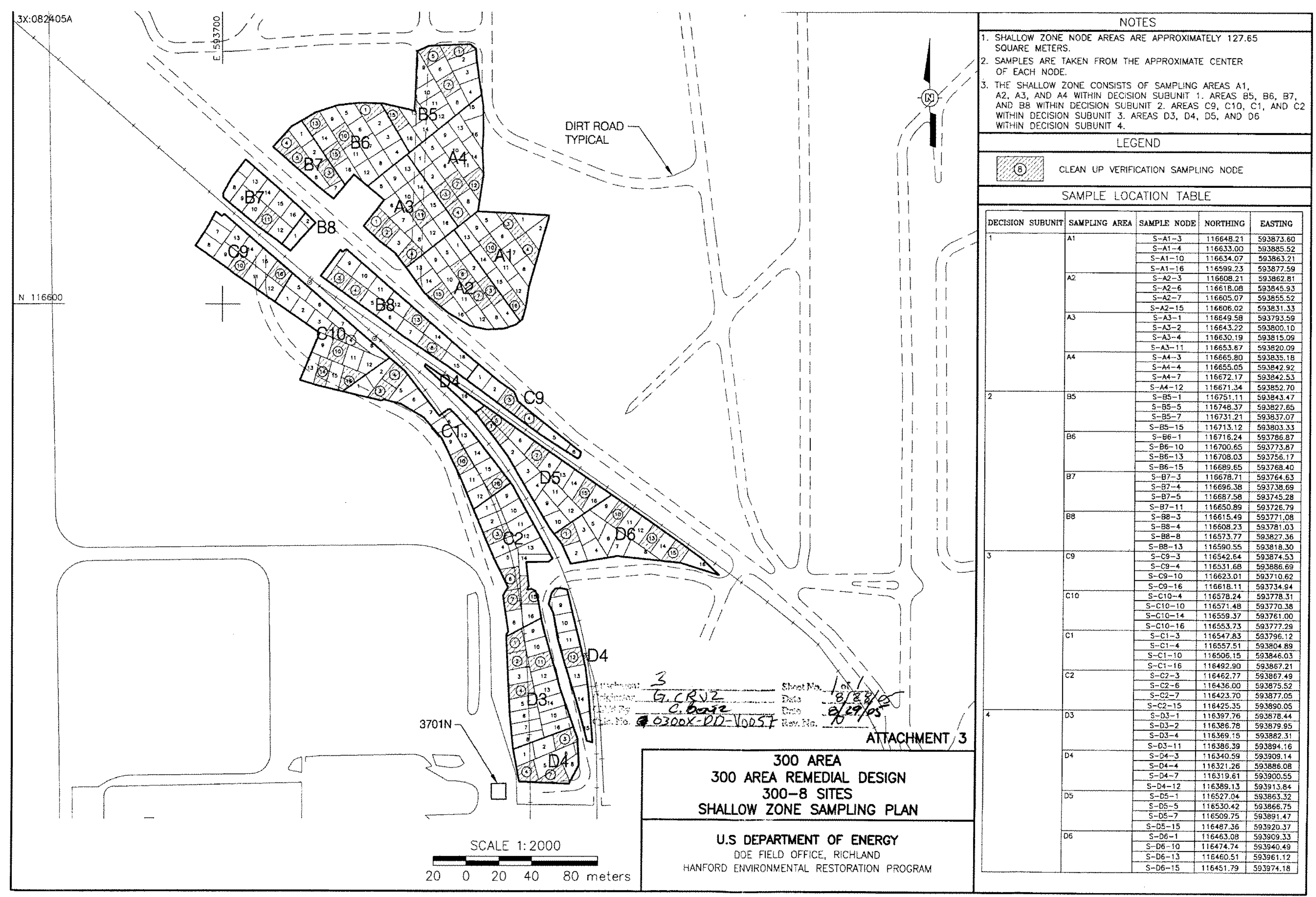


uranium as the primary radiological contaminant. Results of the surveys are depicted on a map based on various ranges of detected uranium activity (Figure 5), with $<50 \mathrm{pCi} / \mathrm{g}$ being the lowest reported range based on instrument sensitivity. Locations where survey results indicated uranium activities $>50 \mathrm{pCi} / \mathrm{g}$ were investigated further in the field by radiological control technicians assigned to the project. Contaminated items identified by the technicians during the field investigation were hand-removed for disposal at the ERDF. Results from the radiological surveys provided an initial indication that residual soil concentrations of uranium were statistically below the applicable cleanup criteria.

\subsection{BIASED SAMPLING AND ANALYSIS}

Biased samples are typically collected at locations where significant quantities of specific waste streams were unearthed from a common area to help verify the absence of hot spots in the residual soil. At the 300-8 waste site, aluminum shavings were spread throughout the excavation rather than being concentrated in any discrete area. No containerized liquid was found, and no evidence of historical liquid disposal was identified during the excavation. Consequently, it was determined that radiological surveys and statistical verification sampling would be adequate for site closeout, and biased samples were not collected as per the approved closeout plan (WCH 2005b).

\subsection{CLEANUP VERIFICATION SAMPLING AND ANALYSIS}

Final cleanup verification samples were collected on July 27 and 28, 2005, to confirm acceptability of residual contaminant concentrations in soil at the 300-8 waste site. Based on the overall footprint of the area and depth of excavation, the 300-8 waste site was classified as four shallow zone decision units. The final verification samples were submitted to offsite laboratories for analysis using approved U.S. Environmental Protection Agency analytical methods as described in the SAP (DOE-RL 2004a).

In accordance with the SAP (DOE-RL 2004a), each verification sample was collected as a composite sample formed by combining soil collected at four random locations within the sampling area (excluding the quality assurance/quality control samples). The sample design methodology and sample location figures are presented in the calculation brief for sample design in Appendix C.

\subsection{CLEANUP VERIFICATION DATA EVALUATION}

This section presents the evaluation and modeling of the 300-8 waste site cleanup verification data for comparison with the data quality criteria and RAGs. 


\subsection{DATA QUALITY ASSESSMENT PROCESS}

A data quality assessment (DQA) is performed to compare the verification sampling approach and resulting analytical data with the sampling and data quality requirements specified by the project objectives and performance specifications.

The DQA for the 300-8 waste site determined that the data are of the right type, quality, and quantity to support site verification decisions within specified error tolerances. All analytical data were found to be acceptable for decision-making purposes.

The evaluation also found that the sample design was sufficient to support clean site verification. The cleanup verification sample analytical data are stored in the Hanford Environmental Information System and are summarized in Appendix A. The detailed DQA is presented in Appendix $B$.

\subsection{CONTAMINANTS OF CONCERN 95\% UPPER CONFIDENCE LIMIT}

The primary statistical calculation to support cleanup verification is the $95 \%$ upper confidence limit (UCL) on the arithmetic mean of the data. Prior to calculating the $95 \%$ $\mathrm{UCL}$, the individual sample results are reviewed and, as appropriate, adjusted per the SAP (DOE-RL 2004a). This process is summarized below.

- Radionuclides: The laboratory-reported value is used in the calculation of the $95 \%$ UCL. In cases where the laboratory does not report a value for data qualified with a "U" (i.e., less than the detection limit), half of the minimum detectable activity is used in the calculation of the $95 \%$ UCL.

- Nonradionuclides: For data flagged with a "U" (i.e., less than detection), a value equal to one-half the practical quantitation limit is used in the calculation of the $95 \%$ $\mathrm{UCL}$, consistent with Washington State Department of Ecology regulations (Washington Administrative Code [WAC] 173-340-740[7][g]). If greater than half of the sample results for a given nonradionuclide $\mathrm{COC}$ are below detection, the statistical value is set equal to the maximum concentration detected (i.e., versus computing a $95 \% \mathrm{UCL}$ ).

Statistical calculations are presented in the 300-8 waste site cleanup verification $95 \%$ $\mathrm{UCL}$ calculation brief (Appendix C). Verification sampling summary statistics (95\% UCL values) are listed in Table 2. The columns on the left side of Table 2 are the COCs and the $95 \%$ UCL values before subtraction of background. The third column of Table 2 presents the background, where values exist, and the last column presents the statistical values adjusted for background, if appropriate, which become the cleanup verification data set used for evaluation against RAGs. Typically, Hanford Site background concentration values are subtracted only for uranium. 


\subsection{SITE-SPECIFIC CLEANUP VERIFICATION MODEL}

A site-specific vadose zone model was not developed for the 300-8 site, as the cleanup verification data set statistical values were all determined to be below statistical background levels, as shown in Table 2.

\subsection{RESRAD MODELING}

A site-specific RESidual RADioactivity (RESRAD) model was not developed for the 300-8 waste site, as the statistical value for total uranium presented in Table 2 was determined to be below the statistical background level as reported in Hanford Site Background: Part 2, Soil Background for Radionuclides (DOE-RL 1996).

Table 2. Cleanup Verification Data Set.

\begin{tabular}{|c|c|c|c|}
\hline coCs & $\begin{array}{c}\text { Shallow Zone 95\% UCL } \\
\text { Statistical Values }\end{array}$ & $\begin{array}{c}\text { Hanford Site } \\
\text { Background }\end{array}$ & $\begin{array}{c}\text { Shallow Zone Cleanup } \\
\text { Verification Data Set }^{{ }^{a}}\end{array}$ \\
\hline \multicolumn{4}{|c|}{ Radionuclide Concentration $(\mathrm{pCi} / \mathrm{g})^{b}$} \\
\hline Uranium (total) & 1.622 & $2.27^{\mathrm{c}}$ & $0(<\mathrm{BG})$ \\
\hline \multicolumn{4}{|c|}{ Nonradionuclide Concentration $(\mathrm{mg} / \mathrm{kg})^{b}$} \\
\hline Beryllium & 0.57 & $1.51^{\mathrm{d}}$ & $0.57(<\mathrm{BG})$ \\
\hline
\end{tabular}

${ }^{a}$ For overburden, anthropogenic background (DOE-RL 1996) and naturally occurring background is subtracted from all radionuclides. For other decision units (e.g., shallow zone and deep zone), naturally occurring background (uranium) is subtracted. Refer to the $95 \%$ UCL calculation brief in Appendix C for additional details on determination of statistical values.

${ }^{b}$ Laboratory data, including the minimum detectable activity or practical quantitation limit for the individual cleanup verification samples, are included in Appendix $A$ and the $95 \%$ UCL calculation brief in Appendix $C$.

"Value published in Hanford Site Background: Part 2, Soil Background for Radionuclides (DOE-RL 1996).

'Value published in Hanford Site Background: Part 1, Soil Background for Nonradioactive Analytes (DOE-RL 2001).

$B G=$ background

$\mathrm{COC}=$ contaminant of concern

$\mathrm{UCL}=$ upper confidence limit

\subsection{EVALUATION OF REMEDIAL ACTION GOAL ATTAINMENT FOR INDUSTRIAL LAND USE}

This section demonstrates that remedial actions at the 300-8 waste site have achieved the RAGs developed to support industrial land use as documented in the RDR/RAWP (DOE-RL 2004b). 


\subsection{DIRECT EXPOSURE SOIL REMEDIAL ACTION GOALS ATTAINED}

\subsubsection{Radionuclides}

5.1.1.1 Direct Comparison to RAGs. The cleanup verification statistical value for total uranium $(1.622 \mathrm{pCi} / \mathrm{g})$ is below the statistical background level $(2.27 \mathrm{pCi} / \mathrm{g})$ and meets the direct exposure RAG of $350 \mathrm{pCi} / \mathrm{g}$, the concentration corresponding to a $15 \mathrm{mrem} / \mathrm{yr}$ excess dose (DOE-RL 2004b). No other radionuclide COCs were identified for the 300-8 waste site.

5.1.1.2 Radionuclide Risk. Residual concentrations of total uranium at the 300-8 waste site were detected below the statistical background value and therefore do not contribute to residual excess carcinogenic risk for the site.

\subsubsection{Nonradionuclides}

5.1.2.1 Direct Comparison to RAGs. Table 3 compares the cleanup verification data set statistical value for beryllium presented in Table 2 to the direct exposure RAG presented in Table 1. The statistical value is less than the corresponding statistical background level and the RAG.

Table 3. Attainment of Nonradionuclide Direct Exposure Standards - Industrial Land Use.

\begin{tabular}{|c|c|c|c|}
\hline Nonradionuclides & $\begin{array}{c}\text { RAG } \\
(\mathrm{mg} / \mathrm{kg})^{\mathrm{a}}\end{array}$ & $\begin{array}{c}\text { Shallow Zone } \\
\text { Verification Data Set } \\
\text { Values } \\
(\mathrm{mg} / \mathrm{kg})\end{array}$ & $\begin{array}{c}\text { Direct Exposure } \\
\text { RAG Attained }^{\mathrm{b}}\end{array}$ \\
\hline Beryllium & 104 & 0.57 & Yes \\
\hline
\end{tabular}

Listed value for industrial land use as presented in Remedial Design Report/Remedial Action Work Plan for the 300 Area (DOE-RL 2004b).

${ }^{\mathrm{b}}$ Criterion is comparison to direct exposure RAG.

$\mathrm{RAG}=$ remedial action goal

5.1.2.2 Noncarcinogenic Hazard Quotient RAG Attained. For noncarcinogenic COCs, WAC 173-340-740(5)(a) and (b) specify the evaluation of the hazard quotient, which is given as daily intake divided by a reference dose (DOE-RL 2001). The hazard quotient for beryllium (the only nonradionuclide $\mathrm{COC}$ ) was not calculated because the associated statistical verification value was less than the statistical background value within the shallow zone.

5.1.2.3 Carcinogenic Risk RAG Attained. For individual nonradionuclide carcinogenic COCs, the WAC 173-340-745(4)(a)(iii) Method C cleanup limits are based on an industrial land-use incremental cancer risk of $1 \times 10^{-5}$. The cumulative excess cancer risk for all nonradionuclide carcinogenic COCs must also be less than $1 \times 10^{-5}$ (WAC 173-340). The only nonradionuclide carcinogenic COC at the 300-8 waste site 
was beryllium, which was detected at less than the applicable background value. Consequently, an excess cancer risk value was not calculated.

\subsection{GROUNDWATER REMEDIAL ACTION GOALS ATTAINED}

\subsubsection{Radionuclides}

The cleanup verification statistical value for total uranium $(1.622 \mathrm{pCi} / \mathrm{g})$ is below the statistical background level $(2.27 \mathrm{pCi} / \mathrm{g})$ and meets the RAG for the protection of groundwater $(267 \mathrm{pCi} / \mathrm{g})$, as calculated by RESRAD based on the exposure scenario (DOE-RL 2004b). No other radionuclide COCs were identified for the 300-8 waste site.

\subsubsection{Nonradionuclides}

Beryllium, the sole nonradionuclide $\mathrm{COC}$ for the 300-8 waste site, is not predicted to reach groundwater within 1,000 years based on a generic site profile for the 300 Area (DOE-RL 2004b). Further, beryllium was not detected above its statistical background level in the cleanup verification data set, as shown in Table 2.

\subsection{COLUMBIA RIVER REMEDIAL ACTION GOALS ATTAINED}

\subsubsection{Radionuclides}

The cleanup verification statistical value for total uranium $(1.622 \mathrm{pCi} / \mathrm{g})$ is below the statistical background level $(2.27 \mathrm{pCi} / \mathrm{g})$ and meets the RAG for the protection of the Columbia River ( $267 \mathrm{pCi} / \mathrm{g}$ ), as calculated by RESRAD based on the exposure scenario and the maximum contaminant level (DOE-RL 2004b). No other radionuclide COCs were identified for the 300-8 waste site.

\subsubsection{Nonradionuclides}

Beryllium, the sole nonradionuclide $\mathrm{COC}$ for the $300-8$ waste site, is not predicted to reach groundwater, and thus the Columbia River, within 1,000 years based on a generic site profile for the 300 Area (DOE-RL 2004b). Further, beryllium was not detected above its statistical background level in the cleanup verification data set, as shown in Table 2. 


\subsection{WAC 173-340 THREE-PART TEST FOR NONRADIONUCLIDES}

The WAC 173-340-740(7)(e) three-part test is applicable to nonradionuclide COCs and consists of the following criteria: (1) the cleanup verification statistical value must be less than the cleanup level, (2) no single detection can exceed two times the cleanup criteria, and (3) the percentage of samples exceeding the cleanup criteria must be less than $10 \%$. The most restrictive RAG (defined as the lowest of the direct exposure, groundwater protection, and river protection RAGs) is used for the test.

Beryllium, the sole nonradionuclide $\mathrm{COC}$ for the 300-8 waste site, was detected at levels less than its statistical background value. Consequently, the WAC 173-340740 (e) three-part test was not performed.

\subsection{EVALUATION OF REMEDIAL ACTION GOAL ATTAINMENT FOR UNRESTRICTED LAND USE}

The information presented in the previous section demonstrates that the cleanup objectives established in the ROD (EPA 2001) for industrial land use have been achieved. In addition, residual soil concentrations indicated that cleanup levels for more stringent land uses may have been achieved for the 300-8 waste site. The information presented in this section evaluates the remedial action results against cleanup criteria established for unrestricted land use to be implemented at selected sites in the 300-FF-2 Operable Unit through the Explanation of Significant Differences for the 300-FF-2 Operable Unit Record of Decision (ESD) (EPA 2004).

The 300 Area unrestricted land-use scenario is represented by an individual in a ruralresidential setting. The exposure pathways considered in estimating dose from radionuclides in soil are inhalation; soil ingestion; ingestion of crops, meat, fish, drinking water, and milk; and external gamma exposure. This individual is conservatively assumed to spend $80 \%$ of his/her lifetime onsite. It is assumed that drinking water and irrigation water are obtained from groundwater, as impacted by the waste site.

Unrestricted land-use cleanup levels for chemicals or nonradionuclides are based on WAC 173-340-740(3), which assumes that the exposure pathway for residual contamination will be from ingestion of contaminated soil. Soil cleanup levels are calculated using the equations provided by WAC 173-340-740(3) for carcinogens and for noncarcinogens. For both carcinogens and noncarcinogens, the calculations assume that a resident with an average body weight $16 \mathrm{~kg}(35 \mathrm{lb})$ over the period of exposure ingests soil at a rate of $200 \mathrm{mg} / \mathrm{day}(73 \mathrm{~g} / \mathrm{yr}$ [ $2.6 \mathrm{oz} / \mathrm{yr}])$, with a frequency of contact of $100 \%$ and a gastrointestinal absorption rate of $100 \%$. For carcinogens, the calculation is based on achieving a lifetime cancer risk goal of 1 in $1,000,000\left(1 \times 10^{-6}\right)$ for an exposure duration of 6 years and a lifetime of 75 years. For noncarcinogens, the calculation is based on achieving a hazard quotient of 1 . 
The key assumptions in the 300 Area unrestricted land-use scenario that affect groundwater protection are irrigation at agronomic rates $(76 \mathrm{~cm} / \mathrm{yr}[30 \mathrm{in} . / \mathrm{yr}])$, surface vegetation resulting in an evapotranspiration coefficient of $91 \%$, and inclusion of drinking water ingestion as an exposure pathway. Details of this land-use scenario and associated RAGs are documented in the ESD (EPA 2004).

A comparison of the 300-8 waste site cleanup verification data set to the cleanup objectives for unrestricted land use as established in the ESD (EPA 2004) is presented in the following section.

\subsection{DIRECT EXPOSURE SOIL REMEDIAL ACTION GOALS ATTAINED}

\subsubsection{Radionuclides}

6.1.1.1 Direct Comparison to RAGs. The cleanup verification statistical value for total uranium $(1.622 \mathrm{pCi} / \mathrm{g})$ is below the statistical background level $(2.27 \mathrm{pCi} / \mathrm{g})$ and meets the direct exposure RAG of $56 \mathrm{pCi} / \mathrm{g}$, the concentration corresponding to a $15 \mathrm{mrem} / \mathrm{yr}$ excess dose (EPA 2004). No other radionuclide COCs were identified for the 300-8 waste site.

6.1.1.2 Radionuclide Risk. Residual concentrations of total uranium at the 300-8 waste site were detected below the statistical background value and therefore do not contribute to residual excess carcinogenic risk for the site.

\subsubsection{Nonradionuclides}

6.1.2.1 Direct Comparison to RAGs. Table 4 compares the cleanup verification data set statistical value for beryllium presented in Table 2 to the direct exposure RAG for unrestricted land use. The statistical value is less than the corresponding statistical background level and the RAG.

Table 4. Attainment of Nonradionuclide Direct Exposure Standards - Unrestricted Land Use.

\begin{tabular}{|c|c|c|c|}
\hline Nonradionuclides & $\begin{array}{c}\text { RAG } \\
(\mathbf{m g} / \mathbf{k g})^{\mathbf{a}}\end{array}$ & $\begin{array}{c}\text { Shallow Zone } \\
\text { Verification Data Set } \\
\text { Values } \\
(\mathrm{mg} / \mathrm{kg})\end{array}$ & $\begin{array}{c}\text { Direct Exposure } \\
\text { RAG Attained }^{\mathbf{b}}\end{array}$ \\
\hline Beryllium & 10.4 & 0.57 & Yes \\
\hline
\end{tabular}

${ }^{a}$ Listed value for unrestricted land use as presented in Explanation of Significant Differences for the 300-FF-2 Operable Unit Record of Decision (EPA 2004).

${ }^{b}$ Criterion is comparison to direct exposure RAG.

$\mathrm{RAG}=$ remedial action goal

6.1.2.2 Noncarcinogenic Hazard Quotient. For noncarcinogenic COCs, WAC 173-340-740(5)(a) and (b) specify the evaluation of the hazard quotient, which is 
given as daily intake divided by a reference dose (DOE-RL 2001). The hazard quotient for beryllium (the only nonradionuclide $\mathrm{COC}$ ) was not calculated because the associated statistical verification value was less than the statistical background value within the shallow zone.

6.1.2.3 Carcinogenic Risk. For individual nonradionuclide carcinogenic COCs, the WAC 173-340-750(3) Method B cleanup limits are based on an unrestricted land-use incremental cancer risk of $1 \times 10^{-6}$. The cumulative excess cancer risk for all nonradionuclide carcinogenic COCs must also be less than $1 \times 10^{-5}$ (WAC 173-340). The only nonradionuclide carcinogenic $\mathrm{COC}$ at the 300-8 waste site was beryllium, which was detected at less than the applicable background value. Consequently, an excess cancer risk value was not calculated.

\subsection{GROUNDWATER REMEDIAL ACTION GOALS ATTAINED}

\subsubsection{Radionuclides}

The cleanup verification statistical value for total uranium $(1.622 \mathrm{pCi} / \mathrm{g})$ is below the statistical background level $(2.27 \mathrm{pCi} / \mathrm{g})$ and meets the RAG for the protection of groundwater $(37 \mathrm{pCi} / \mathrm{g})$, as calculated by RESRAD based on the exposure scenario (EPA 2004). No other radionuclide COCs were identified for the 300-8 waste site.

\subsubsection{Nonradionuclides}

Beryllium, the sole nonradionuclide $\mathrm{COC}$ for the $300-8$ waste site, is not predicted to reach groundwater within 1,000 years based on a generic site profile for the 300 Area (DOE-RL 2004b). Further, beryllium was not detected above its statistical background level in the cleanup verification data set, as shown in Table 2.

\subsection{COLUMBIA RIVER REMEDIAL ACTION GOALS ATTAINED}

\subsubsection{Radionuclides}

The cleanup verification statistical value for total uranium $(1.622 \mathrm{pCi} / \mathrm{g})$ is below the statistical background level $(2.27 \mathrm{pCi} / \mathrm{g})$ and meets the RAG for the protection of the Columbia River $(74 \mathrm{pCi} / \mathrm{g})$, as calculated by RESRAD based on the exposure scenario (DOE-RL 2004b). No other radionuclide COCs were identified for the 300-8 waste site.

\subsubsection{Nonradionuclides}

Beryllium, the sole nonradionuclide $\mathrm{COC}$ for the 300-8 waste site, is not predicted to reach groundwater, and thus the Columbia River, within 1,000 years based on a generic site profile for the 300 Area (DOE-RL 2004b). Further, beryllium was not detected above its statistical background level in the cleanup verification data set, as shown in Table 2. 


\subsection{WAC 173-340 THREE-PART TEST FOR NONRADIONUCLIDES}

Beryllium, the sole nonradionuclide $\mathrm{COC}$ for the $300-8$ waste site, was detected at levels less than its statistical background value. Consequently, the WAC 173-340740(e) three-part test was not performed.

\subsection{STATEMENT OF PROTECTIVENESS}

This cleanup verification package demonstrates that remedial action at the 300-8 waste site has achieved the RAOs and corresponding RAGs established in the ROD (EPA 2001) and RDR/RAWP (DOE-RL 2004b). The contaminated materials from the site have been excavated and disposed at ERDF. Results of post-remediation geophysical surveys demonstrate that only trace levels of metallic debris remain at the site. The remaining soil at the 300-8 site has been sampled, analyzed, and evaluated. Results indicate that the site supports future land uses that can be represented (or bounded) by the industrial land-use scenario and poses no threat to groundwater or the Columbia River. Consequently, the 300-8 waste site is verified to be remediated in accordance with the ROD.

Because residual soil concentrations indicated that cleanup levels for more stringent land uses may have been achieved for the 300-8 waste site, a supplemental evaluation was performed against the unrestricted land-use RAGs established for the 300 Area in the ESD (EPA 2004). This evaluation demonstrated that the results of verification sampling do not preclude any future uses (as bounded by the rural-residential scenario) and allow unrestricted use of shallow zone soils. In consideration of this and because the site has no deep zone, no institutional controls are required at the 300-8 waste site.

\subsection{REFERENCES}

40 CFR 141, "National Primary Drinking Water Regulations," Code of Federal Regulations, as amended.

65 FR 76708, "National Primary Drinking Water Regulations; Radionuclides; Final Rule," Federal Register, Vol. 65, No. 236, p. 76708, December 7, 2000.

BHI, 2001, Calculation of Total Uranium Activity Corresponding to a Maximum Contaminant Level for Total Uranium of 30 Micrograms per Liter in Groundwater, 0100X-CA-V0038, Rev. 0, Bechtel Hanford, Inc., Richland, Washington. 
Comprehensive Environmental Response, Compensation, and Liability Act of 1980, 42 U.S.C. 601 , et seq.

DOE Order 5400.5, Radiation Protection of the Public and the Environment, U.S. Department of Energy, Washington, D.C.

DOE-RL, 1996, Hanford Site Background: Part 2, Soil Background for Radionuclides, DOE/RL-96-12, Rev. 0, U.S. Department of Energy, Richland Operations Office, Richland, Washington.

DOE-RL, 1997, Limited Field Investigation Report for the 300-FF-2 Operable Unit, DOE/RL-96-42, Rev. 0, U.S. Department of Energy, Richland Operations Office, Richland, Washington.

DOE-RL, 1998, Tri-Party Agreement Handbook Management Procedures, RL-TPA-90-0001, Guideline Number TPA-MP-14, "Maintenance of the Waste Information Data System (WIDS)," U.S. Department of Energy, Richland Operations Office, Richland, Washington.

DOE-RL, 2001, Hanford Site Background: Part 1, Soil Background for Nonradioactive Analytes, DOE/RL-92-24, Rev. 4, U.S. Department of Energy, Richland Operations Office, Richland, Washington.

DOE-RL, 2004a, 300 Area Remedial Action Sampling and Analysis Plan, DOE/RL-2001-48, Rev. 1, U.S. Department of Energy, Richland Operations Office, Richland, Washington.

DOE-RL, 2004b, Remedial Design Report/Remedial Action Work Plan for the 300 Area, DOE/RL-2001-47, Rev. 1, U.S. Department of Energy, Richland Operations Office, Richland, Washington.

Ecology, EPA, and DOE, 1989, Hanford Federal Facility Agreement and Consent Order, 2 vols., as amended, Washington State Department of Ecology,

U.S. Environmental Protection Agency, and U.S. Department of Energy, Olympia, Washington.

EPA, 2001, Record of Decision for the 300-FF-2 Operable Unit, Hanford Site,

U.S. Environmental Protection Agency, Region 10, Seattle, Washington.

EPA, 2004, Explanation of Significant Differences for the 300-FF-2 Operable Unit Record of Decision, U.S. Environmental Protection Agency, Region 10, Seattle, Washington.

WAC 173-340, 1996, "Model Toxics Control Act - Cleanup" Washington Administrative Code. 
WCH, 2005a, 300-8 Aluminum Shavings Area Geophysical Survey, CCN 122368 , Washington Closure Hanford, Richland, Washington.

WCH, 2005b, Closeout Plan for Waste Site 300-8, CCN 123843, Washington Closure Hanford, Richland, Washington. 
CVP-2005-00007

Rev. 0 
CVP-2005-00007

Rev. 0

APPENDIX A

SUMMARY OF VERIFICATION SOIL SAMPLING AND ANALYTICAL RESULTS 
CVP-2005-00007

Rev. 0

A-ii 
Table A-1. 300-8 Shallow Zone Cleanup Verification Data.

\begin{tabular}{|c|c|c|c|c|c|c|c|c|}
\hline \multirow{2}{*}{$\begin{array}{c}\text { Sampling } \\
\text { Area }\end{array}$} & \multirow{2}{*}{$\begin{array}{c}\text { HEIS } \\
\text { Number }\end{array}$} & \multirow{2}{*}{$\begin{array}{c}\text { Sample } \\
\text { Date }\end{array}$} & \multicolumn{3}{|c|}{ Beryllium } & \multicolumn{3}{|c|}{ Uranium (Total) $^{\mathrm{a}}$} \\
\hline & & & $\mathrm{mg} / \mathrm{kg}$ & Q & PQL & $\mathrm{pCi} / \mathrm{g}$ & $\mathbf{Q}$ & MDA \\
\hline $\mathrm{A} \uparrow$ & J03VD4 & $7 / 27 / 05$ & 4.7E-01 & & $9 E-03$ & $1.341 E+00$ & & 1.9E-01 \\
\hline $\begin{array}{l}\text { Duplicate of } \\
\text { J03VD4 }\end{array}$ & J03VHO & $7 / 27 / 05$ & $6.0 \mathrm{E}-01$ & & $9 E-03$ & $1.095 E+00$ & & $2.4 E-01$ \\
\hline $\begin{array}{l}\text { Split of } \\
\text { J03VD4 }\end{array}$ & J03VH1 & $7 / 27 / 05$ & $5.3 \mathrm{E}-01$ & & $5.0 E-01$ & $1.487 E+00$ & & $1.17 \mathrm{E} 01$ \\
\hline $\mathrm{A} 2$ & J03VD5 & $7 / 27 / 2005$ & 4.9E-01 & & 9.E-03 & $1.141 E+00$ & & $1.8 \mathrm{E}-01$ \\
\hline $\mathrm{A} 3$ & J03VD6 & $7 / 27 / 2005$ & 4.9E-01 & & $9 . E-03$ & $1.145 \mathrm{E}+00$ & & $2.0 \mathrm{E}-01$ \\
\hline A4 & J03VD7 & $7 / 27 / 2005$ & 5.1E-01 & & $9 . \mathrm{E}-03$ & $1,171 \mathrm{E}+00$ & & $1.9 \mathrm{E}-01$ \\
\hline B5 & J03VD8 & $7 / 27 / 2005$ & 6.1E-01 & & 1.E-02 & $1.449 E+00$ & & $2.1 \mathrm{E} \sim 01$ \\
\hline B6 & J03VD9 & $7 / 27 / 2005$ & $5.4 \mathrm{E}-01$ & & 9.E-03 & $1.204 E+00$ & & $1.8 E-01$ \\
\hline B7 & J03VF0 & $7 / 27 / 2005$ & 5.3E-01 & & 9.E-03 & $1.133 E+00$ & & $2.0 \mathrm{E}-01$ \\
\hline 88 & J03VF1 & $7 / 27 / 2005$ & $6.0 \mathrm{E}-01$ & & $9 . E-03$ & $1.190 E+00$ & & $1.9 \mathrm{E} \sim 01$ \\
\hline $\mathrm{Cg}$ & J03VF2 & $7 / 28 / 2005$ & $5.5 E-01$ & & 9.E-03 & $1.089 E+00$ & & $1.9 \mathrm{E}-01$ \\
\hline $\mathrm{C} 10$ & J03VF3 & $7 / 28 / 2005$ & $6.5 \mathrm{E} \sim 01$ & & 9.E-03 & $1.124 E+00$ & & $1.7 \mathrm{E}-01$ \\
\hline $\mathrm{C} 1$ & J03VF4 & $7 / 28 / 2005$ & $5.7 E-01$ & & $9 . E-03$ & $6.92 \mathrm{E}-01$ & & $1.9 \mathrm{E}-01$ \\
\hline $\mathrm{C} 2$ & J03VF5 & $7 / 28 / 2005$ & 5.7E-01 & & 9.E-03 & $2.081 E+00$ & & 1.8E-01 \\
\hline D3 & J03VF6 & $7 / 28 / 2005$ & $5.5 \mathrm{E}-01$ & & 9.E-03 & $1.763 E+00$ & & $2.0 \mathrm{E}-01$ \\
\hline D4 & J03VF7 & $7 / 28 / 2005$ & $5.2 E-01$ & & 9.E -03 & $3.175 E+00$ & & $1.9 \mathrm{E}-01$ \\
\hline D5 & J03VF8 & $7 / 28 / 2005$ & 5.1E-01 & & 9.E-03 & $1.646 E+00$ & & $2.1 E+01$ \\
\hline D6 & J03VF9 & $7 / 28 / 2005$ & $5.8 \mathrm{E}-01$ & & 9.E-03 & $8.950 E-01$ & & $1.9 E-01$ \\
\hline
\end{tabular}

${ }^{a}$ Reported total uranium value is based on summation of laboratory-reported isotopic uranium concentrations. Reported MDA is calculated as the average of laboratory-reported isotopic MDA values.

HEIS = Hanford Environmental Information System

$\mathrm{MDA}=$ minimum detectable activity

$\mathrm{PQL}$ = practical quantitation limit

$\mathrm{Q} \quad$ = qualifier 
CVP-2005-00007

Rev. 0

A-2 
CVP-2005-00007

Rev. 0

APPENDIX B

DATA QUALITY ASSESSMENT

$B-i$ 
CVP-2005-00007

Rev. 0

B-ii 


\section{APPENDIX B}

\section{DATA QUALITY ASSESSMENT FOR THE 300-8 WASTE SITE}

\section{B1.1 OVERVIEW}

This DQA was performed in accordance with BHI-EE-01, Environmental Investigations Procedures. Specific data quality objectives for the site are found in the 300 Area Remedial Action Sampling and Analysis Plan (SAP) (DOE-RL 2004a). The DQA is based on the guidelines presented in Guidance for Data Quality Assessment (EPA 2000). Statistical tests used in this DQA were performed as specified in the SAP and the Remedial Design Report/Remedial Action Work Plan for the 300 Area (RDR/RAWP) (DOE-RL 2004b). This DQA involves the scientific and statistical evaluations to determine if the data are of the right type, quality, and quantity to support the intended use (i.e., closeout decisions [EPA 2000]). This DQA completes the data life cycle (i.e., planning, implementation, and assessment) that was initiated by the data quality objectives process.

Prior to performing statistical tests, the field logbook (BHI 2005a), sample design, and sample analytical data are evaluated. A portion of the cleanup verification sample analytical data are validated for compliance requirements (DOE-RL 2004b). Data evaluation is performed to determine if the laboratory carried out all steps required by the SAP (DOE-RL 2004a) and the laboratory contract governing the conduct of the analysis and reporting of the data. This assessment also examines the available laboratory data to determine what analytes are present or absent in a sample and the degree of overall uncertainty associated with that determination. Data validation is done in accordance with validation procedures (BHI 2000a, 2000b) as part of data evaluation. After data evaluation and validation, the appropriate statistical test is performed on the adjusted raw analytical data (see calculation briefs in Appendix C) to determine statistical values for each contaminant. The cleanup verification sample analytical data are stored in the Hanford Environmental Information System and are summarized in Appendix A.

\section{B1.2 LABORATORY QUALITY ASSURANCE/QUALITY CONTROL MEASURES}

All verification samples are subject to laboratory-specific quality assurance (QA) requirements, including instrument procurement, maintenance, calibration, and operation. Additional laboratory quality control (QC) checks are performed as specified by the analytical method, at a rate of once per sample delivery group (SDG), or once for every 20 samples, whichever is more frequent. Laboratory internal QC checks include the following:

- Laboratory Contamination: Each analytical batch contains a laboratory (method) blank (material of similar composition as the samples with known/minimal 
contamination of the analytes of interest) carried through the complete analytical process. The method blank is used to evaluate false-positive results in samples due to contamination during handling at the laboratory.

- Analytical Accuracy: For most analyses, known quantities of representative analytes of interest (matrix spike [MS]) are added to a separate aliquot of a sample from the analytical batch. The recovery percentage of the added MS is used to evaluate analytical accuracy. For analyses not amenable to MS techniques (e.g., gamma energy analysis) or where analytical recovery is corrected via internal standards (e.g., alpha spectral analyses), accuracy is evaluated from recovery of the QC reference sample (e.g., laboratory control spike or blank spike sample).

- Analytical Precision: Separate aliquots removed from one or more of the same sample containers (replicate samples) are analyzed for each analytical batch. The replicate sample results (evaluated as relative percent differences [RPDs]) are used to assess analytical precision.

- QC Reference Samples: A QC reference sample is prepared from an independent standard at a concentration other than that used for calibration, but within the calibration range. Reference samples provide an independent check on analytical technique, methodology, and quantitation.

Laboratories are also subject to periodic and random assessments of overall performance. These assessments are performed by the Washington Closure Hanford QA group to ensure that the laboratories are performing within laboratory contract requirements.

\section{B1.3 DATA VALIDATION}

The final laboratory data package for SDG H3292 (containing all verification samples and analyses) was validated to Level C per BHI-EE-01, Procedure 2.5, "Data Package Validation Process," by a third-party validator. Level $\mathrm{C}$ validation procedures are specified in Data Validation Procedure for Chemical Analysis (BHI 2000a) and Data Validation Procedure for Radiochemical Analysis (BHI 2000b).

Use of level $\mathrm{C}$ validation procedures included the review of the following items, as appropriate, for each analytical method:

- Sample holding times

- Method blanks

- MS recovery

- Surrogate recovery

- MS/matrix spike duplicate results

- Sample replicates

- Associated batch laboratory control sample results 
- Achievement of required (or contractual) detection limits (RDLs)

- Data package completeness.

The laboratory QA/QC was evaluated for precision, accuracy, completeness, and RDLs pursuant to the SAP (DOE-RL 2004a). The organization performing the data validation reported that, of the data validated, the laboratory met the standards of performance for precision $( \pm 30 \%)$, accuracy $( \pm 30 \%)$, and completeness $(>90 \%)$. Comparison of the $\mathrm{RDL}$ with the respective MDA or PQL is discussed in Section B1.4.

The validation process did not identify any major or minor deficiencies in the sample results. Consequently, no data qualifiers were assigned to the reported results through the validation process. Additional information is provided in the associated validation reports (BHI 2005b, 2005c).

\section{B1.4 DATA EVALUATION}

The context for assessing the data includes evaluating the sample data using the statistical methodology of the SAP (DOE-RL 2004a) (included in the calculation brief excerpts in Appendix C) and a comparison of analytical results to the parameters specified in the SAP. This section summarizes the results of the comparison and presents an evaluation of the affected data.

\section{B1.4.1 RDL Comparison}

Reported analytical detection levels for nondetected analytes were compared to the RDLs specified in the SAP (DOE-RL 2005a). When detected results are obtained, evaluation of detection limits is not performed. The data validation and supplemental data evaluation noted no analyses for which the detection limits (MDA or PQL) were above SAP RDLs for nondetected analytes.

\section{B1.4.2 Precision and Accuracy Evaluation}

Analytical accuracy and precision were evaluated by examination of the percent recovery and RPD of analytical spikes (MS and/or laboratory control samples) between the main and duplicate samples. Only the contaminants of concern (COCs) detected at more than five times the detection limit are used for data analysis with respect to accuracy and precision. The RPDs for all laboratory duplicates and the recoveries for all laboratory spikes were within acceptable limits.

\section{B1.5 FIELD QUALITY ASSURANCE/QUALITY CONTROL}

Field QA/QC measures were used to assess potential sources of error and crosscontamination of soil samples that could bias results. Field QA/QC samples included the following: 
- Duplicate J03VH0, associated with sample J03VD4, and

- Split J03VH1, associated with sample J03VD4.

All main and QAVQ sample results are presented in Appendix A.

\section{B1.5.1 Field Duplicate Samples}

A duplicate sample was collected to provide a relative measure of the degree of local heterogeneity in the sampling medium, unlike laboratory duplicates that are used to evaluate precision in the analytical process. The field duplicates are evaluated by computing the RPD of the duplicate samples for each COC. Only analytes with values more than five times the contractual RDLs for both the main and duplicate samples are compared. Based on these criteria, RPD analysis was not required for the 300-8 waste site verification sample duplicate pair. The $95 \%$ upper confidence limit calculation brief in Appendix $\mathrm{C}$ provides details on duplicate pair evaluation and RPD calculation.

\section{B1.5.2 Field Split Samples}

A split sample was collected to provide a relative measure of the degree of variability in the sampling, sample handling, and analytical techniques used by commercial laboratories. The field main and split samples are evaluated by computing the RPD of the split samples for each $\mathrm{COC}$ to determine the usability of the verification data. The U.S. Environmental Protection Agency Contract Laboratory Program duplicate sample comparison methodology, USEPA Contract Laboratory Program National Functional Guidelines for Inorganic Data Review (EPA 1994), is used as an initial test of the data from the splits. Only analytes that had values more than five times the contractual RDL for both the main and split sample were compared. Based on these criteria, RPD analysis was not required for the split pair. The $95 \%$ upper confidence limit calculation brief in Appendix $C$ provides details on split pair evaluation and RPD calculation.

\section{B1.6 SUITABILITY OF DATA}

The DQA for the 300-8 site determined that the data are of the right type, quality, and quantity to support site cleanup verification decisions within specified error tolerances. The evaluation verified that the sample design was sufficient for the purpose of clean site verification. All analytical data were found to be acceptable for decision-making purposes and acceptable for calculating the required statistical values.

\section{B2.0 REFERENCES}

BHI, 2000a, Data Validation Procedure for Chemical Analysis, BHI-01435, Rev. 0, Bechtel Hanford, Inc., Richland, Washington. 
BHI, 2000b, Data Validation Procedure for Radiochemical Analysis, BHI-01433, Rev. 0, Bechtel Hanford, Inc., Richland, Washington.

BHI, 2005a, 300-FF-1/2 Analytical Field Services Logbook, EFL-1395-11, Bechtel Hanford, Inc., Richland, Washington.

BHI, 2005b, Data Validation Package - Inorganics (SDG No. H3292), Bechtel Hanford, Inc., Richland, Washington.

BHI, 2005c, Data Validation Package - Radiochemistry (SDG No. H3292), Bechtel Hanford, Inc., Richland, Washington.

BHI-EE-01, Environmental Investigations Procedures, Bechtel Hanford, Inc., Richland, Washington.

DOE-RL, 2004a, 300 Area Remedial Action Sampling and Analysis Plan, DOE/RL-2001-48, Rev. 1, U.S. Department of Energy, Richland Operations Office, Richland, Washington.

DOE-RL, 2004b, Remedial Design Report/Remedial Action Work Plan for the 300 Area, DOE/RL-2001-47, Rev. 1, U.S. Department of Energy, Richland Operations Office, Richland, Washington.

EPA, 1994, USEPA Contract Laboratory Program National Functional Guidelines for Inorganic Data Review, EPA 540/R-94/013, U.S. Environmental Protection Agency, Washington, D.C.

EPA, 2000, Guidance for Data Quality Assessment, EPA QA/G-9, QA00 Update, U.S. Environmental Protection Agency, Office of Environmental Information, Washington, D.C. 
CVP-2005-00007

Rev. 0

B-6 
CVP-2005-00007

Rev. 0

\section{APPENDIX C}

CALCULATION BRIEF EXCERPTS 
CVP-2005-00007

Rev. 0

\section{DISCLAIMER FOR CALCULATIONS}

The attached calculations have been generated for a specific purpose and task. Use of these calculations by persons who do not have access to all pertinent facts may lead to incorrect conclusions and/or results. Before applying these calculations to your work, the underlying basis, rationale, and other pertinent information relevant to these calculations must be thoroughly reviewed with appropriate $\mathrm{WCH}$ officials or other authorized personnel. The WCH is not responsible for the use of a calculation not under its direct control. 


\section{CALCULATION BRIEFS}

The following calculation briefs have been prepared in accordance with BHI-DE-01, Design Engineering Procedures Manual, EDPI-4.37-01, "Project Calculations," Bechtel Hanford, Inc., Richland, Washington.

300-8 Sites Shallow Zone Sampling Plan, 0300X-CA-V0057, Rev. 0, Bechtel Hanford, Inc., Richland, Washington.

300-8 Waste Site Cleanup Verification 95\% UCL Calculation, 0300X-CA-V0056, Rev. 0, Washington Closure Hanford, Richland, Washington.

NOTE: The calculation briefs referenced in this appendix are kept in the active Washington Closure Hanford project files and are available upon request. When the project is completed, the files will be stored in a U.S. Department of Energy, Richland Operations Office, repository. Only excerpts of the calculation briefs are included in this appendix. 
CVP-2005-00007

Rev. 0

C-2 


\section{CALCULATION COVER SHEET}

Project Title:

Area

Discipline

Subject

Computer Program
300-8 Sites Sample Design

Job No.

22192
Environmental Engineering 300-8 Sites Shallow Zone Sampling Plan Program No. Excel 2003

The attached calculations have been generated to document compliance with established cleanup levels. These documents should be used in conjuction with other relevent documents in the administrative record.

\section{Committed Calculation}

区

Preliminary

Superseded

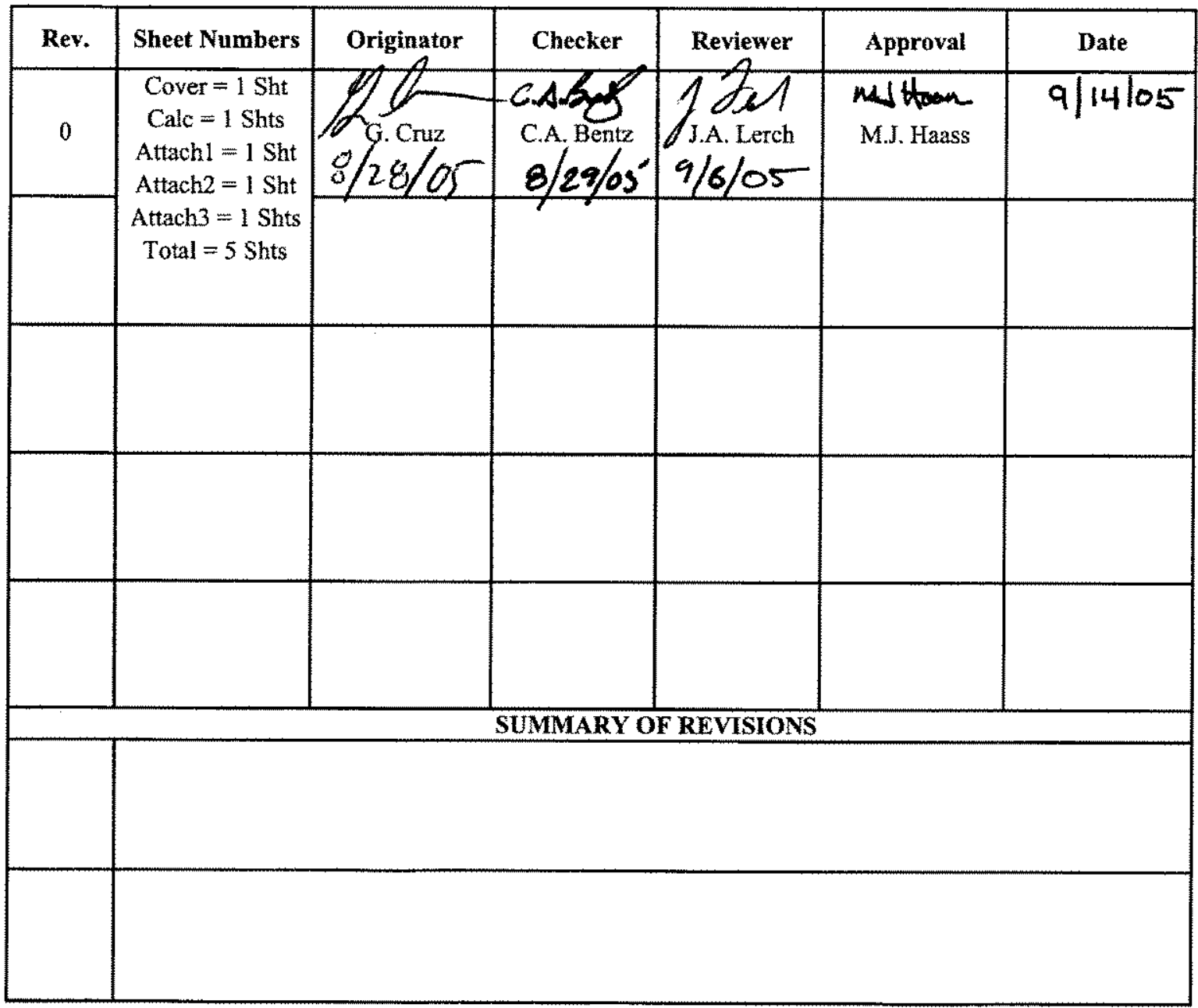


Date 8/24/2005

Project 300-8 Sites Sample Design

Subject $300-8$ Sites Shallow Zone Sampling Plan
Calc. No. 0300X-CA-V0057 Rev. No. 0

Job No. 22192

Checked $\triangle B$ Date

Sheet No. 1 of 1

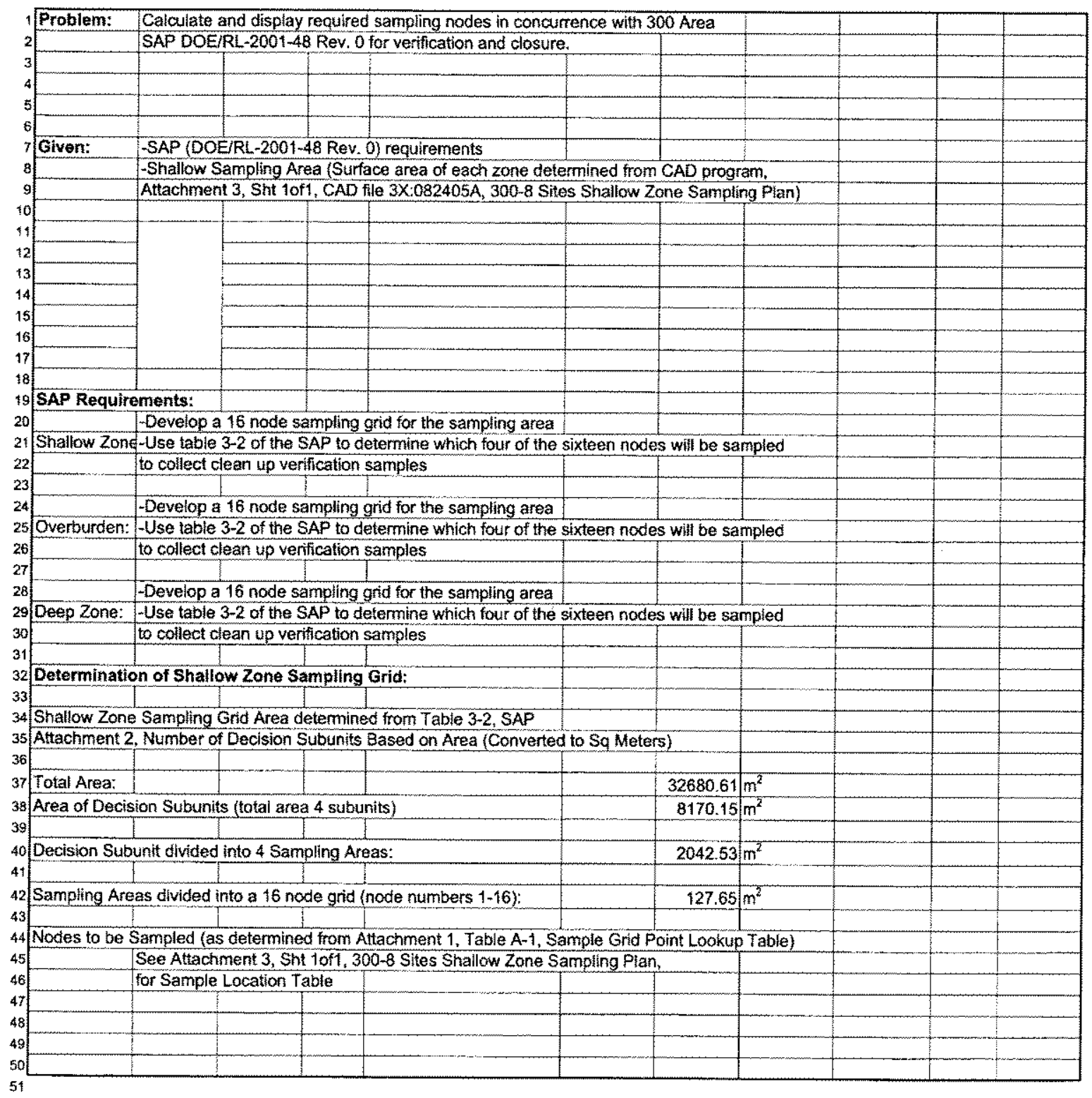


Originator

Project 300-8 Sites Sample Design Job No. 22192

Subject 300-8 Sites Shallow Zone Sampling Plan Sheet No 1 of 1

\section{ATTACHMENT 1}

${ }_{3}$ Sample Grid Point Lookup Table.

4

\begin{tabular}{|c|c|c|c|c|c|c|c|c|c|c|}
\hline Defautt Plan & $\begin{array}{c}\text { Sampiling } \\
\text { Area } 1\end{array}$ & $\begin{array}{c}\text { Sampling } \\
\text { Area 2 }\end{array}$ & $\begin{array}{c}\text { Sampling } \\
\text { Ares } 3\end{array}$ & $\begin{array}{c}\text { Sampiling } \\
\text { Area } 4\end{array}$ & $\begin{array}{c}\text { Sampling } \\
\text { Area } 5\end{array}$ & $\begin{array}{c}\text { Sampling } \\
\text { Aras } 6\end{array}$ & $\begin{array}{c}\text { Sampling } \\
\text { Amea } 7\end{array}$ & $\begin{array}{c}\text { Sampling } \\
\text { Area } 8\end{array}$ & $\begin{array}{c}\text { Sampling } \\
\text { Arae } 9\end{array}$ & $\begin{array}{c}\text { Ssmpling } \\
\text { Ares to }\end{array}$ \\
\hline Closeout & 3 & 6 & 1 & 4 & 5 & 1 & 3 & 3 & 4 & $1 \mathfrak{B}$ \\
\hline Closeout & 4 & 7 & 11 & 3 & 15 & 15 & 5 & 13 & 10 & 10 \\
\hline Closeout & 16 & 3 & 2 & 7 & 7 & 10 & 11 & 4 & 3 & 14 \\
\hline Closeout & 10 & 15 & 4 & 12 & 1 & 73 & 4 & 8 & 16 & 4 \\
\hline Not Sampling & 2 & 14 & 5 & 9 & 13 & 12 & 8 & 2 & 14 & 8 \\
\hline Not Sampling & 13 & 10 & 9 & 13 & 2 & 16 & 1 & 12 & 5 & 3 \\
\hline Not Sampling & 6 & 1 & 10 & 8 & 14 & 4 & 16 & 5 & 8 & 6 \\
\hline Not Sampling & 1 & 9 & 13 & 1 & 10 & 5 & 12 & 1 & 1 & 15 \\
\hline Not Sampling & 9 & 12 & 7 & 5 & 6 & 2 & 6 & 7 & 15 & 9 \\
\hline Not Sampiñng & 15 & 16 & 15 & 14 & 16 & 6 & 2 & 15 & 11 & 1 \\
\hline Not Sampling & 8 & 13 & 8 & 10 & 12 & 11 & 13 & 14 & 2 & 12 \\
\hline Not Sampling & 5 & 2 & 3 & 11 & 4 & 3 & 9 & 10 & 7 & 11 \\
\hline Not Sampling & 7 & 11 & 14 & 15 & 11 & 14 & 14 & 6 & 13 & 2 \\
\hline Not Sampling & 11 & 4 & 6 & 2 & 9 & 7 & 7 & 11 & 9 & 7 \\
\hline Not Sampling & 12 & 8 & 16 & 16 & 3 & 8 & 15 & 9 & 6 & 13 \\
\hline Not Sampling & 14 & 5 & 12 & 6 & 8 & 9 & 10 & 16 & 12 & 5 \\
\hline
\end{tabular}


Project $\quad 300-8$ Sites Sample Design Job No. 22192 checked $\triangle B$ Date $8 / 29 / 05$

Subject $300-8$ Sites Shallow Zone Sampling Plan Sheet No. 1of1

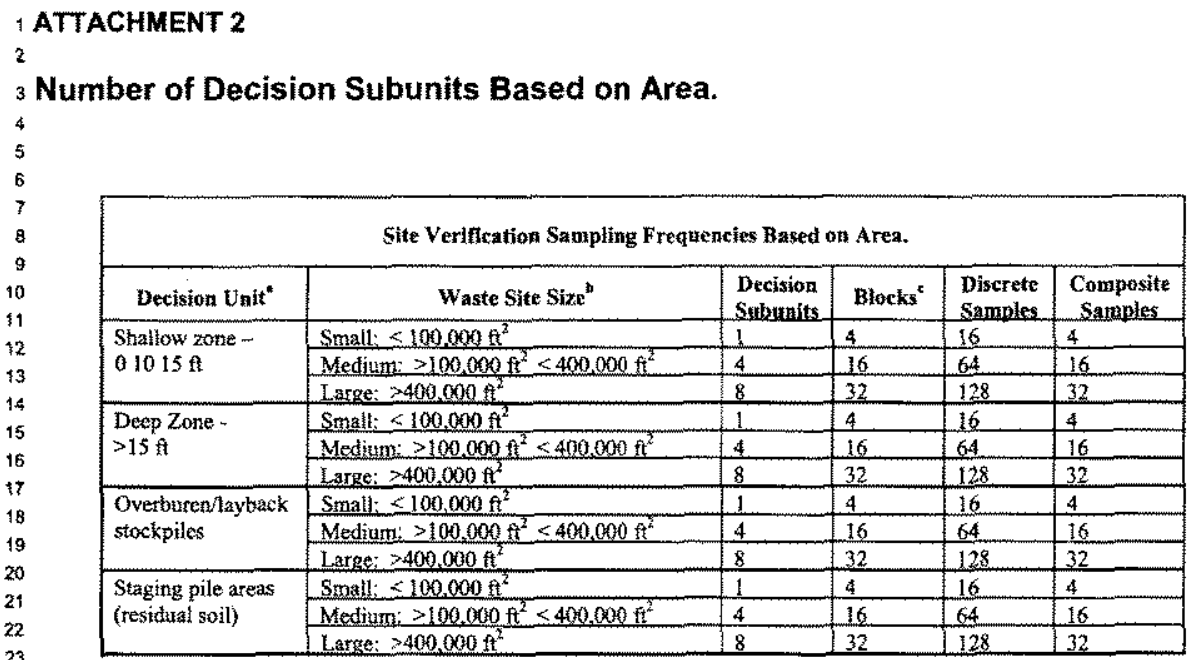

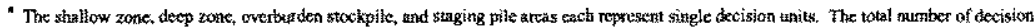
units will vary because individual waste sites may not beve a deep zone, overburden steckpilie, andilor staging pile arzas.

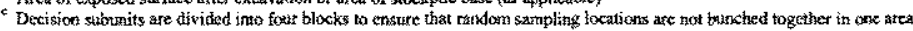

